\title{
The PMIP4 contribution to CMIP6 - Part 2: Two interglacials, scientific objective and experimental design for Holocene and Last Interglacial simulations
}

Bette L. Otto-Bliesner ${ }^{1}$, Pascale Braconnot ${ }^{2}$, Sandy P. Harrison ${ }^{3}$, Daniel J. Lunt ${ }^{4}$, Ayako Abe-Ouchi ${ }^{5,6}$, Samuel Albani $^{7}$, Patrick J. Bartlein ${ }^{8}$, Emilie Capron ${ }^{9,10}$, Anders E. Carlson ${ }^{11}$, Andrea Dutton ${ }^{12}$, Hubertus Fischer ${ }^{13}$, Heiko Goelzer ${ }^{14,15}$, Aline Govin ${ }^{2}$, Alan Haywood ${ }^{16}$, Fortunat Joos ${ }^{13}$, Allegra N. LeGrande ${ }^{17}$, William H. Lipscomb ${ }^{18}$, Gerrit Lohmann ${ }^{19}$, Natalie Mahowald ${ }^{20}$, Christoph Nehrbass-Ahles ${ }^{13}$, Francesco S. R. Pausata ${ }^{21}$, Jean-Yves Peterschmitt ${ }^{2}$, Steven J. Phipps ${ }^{22}$, Hans Renssen ${ }^{23,24}$, and Qiong Zhang ${ }^{25}$

${ }^{1}$ National Center for Atmospheric Research, 1850 Table Mesa Drive, Boulder, CO 80305, USA

${ }^{2}$ Laboratoire des Sciences du Climat et de l'Environnement, LSCE/IPSL, CEA-CNRS-UVSQ, Université Paris-Saclay, 91191 Gif-sur-Yvette, France

${ }^{3}$ Centre for Past Climate Change and School of Archaeology, Geography and Environmental Science (SAGES), University of Reading, Whiteknights, RG6 6AH, Reading, UK

${ }^{4}$ School of Geographical Sciences, University of Bristol, Bristol, BS8 1SS, UK

${ }^{5}$ Atmosphere Ocean Research Institute, University of Tokyo, 5-1-5, Kashiwanoha, Kashiwa-shi, Chiba 277-20 8564, Japan

${ }^{6}$ Japan Agency for Marine-Earth Science and Technology, 3173-25 Showamachi, Kanazawa, Yokohama, Kanagawa, 236-0001, Japan

${ }^{7}$ Institute for Geophysics and Meteorology, University of Cologne, Cologne, Germany

${ }^{8}$ Department of Geography, University of Oregon, Eugene, OR 97403-1251, USA

${ }^{9}$ Centre for Ice and Climate, Niels Bohr Institute, University of Copenhagen, Juliane Maries Vej 30,

2100 Copenhagen $\varnothing$, Denmark

${ }^{10}$ British Antarctic Survey, High Cross Madingley Road, Cambridge CB3 0ET, UK

${ }^{11}$ College of Earth, Ocean, and Atmospheric Sciences, Oregon State University, Corvallis, OR 97331, USA

${ }^{12}$ Department of Geological Sciences, University of Florida, Gainesville, FL 32611, USA

${ }^{13}$ Climate and Environmental Physics, Physics Institute and Oeschger Centre for Climate Change Research, University of Bern, 3012 Bern, Switzerland

${ }^{14}$ Institute for Marine and Atmospheric Research Utrecht (IMAU), Utrecht University, Princetonplein 5, 3584 CC Utrecht, the Netherlands

${ }^{15}$ Laboratoire de Glaciologie, Université Libre de Bruxelles, CP160/03, Av. F. Roosevelt 50, 1050 Brussels, Belgium

${ }^{16}$ School of Earth and Environment, University of Leeds, Woodhouse Lane, Leeds, West Yorkshire, LS29JT, UK

${ }^{17}$ NASA Goddard Institute for Space Studies, 2880 Broadway, New York, NY 10025, USA

${ }^{18}$ Group T-3, Fluid Dynamics and Solid Mechanics, Los Alamos National Laboratory, Los Alamos, NM 87545, USA

${ }^{19}$ Alfred Wegener Institute Helmholtz Centre for Polar and Marine Research Bussestr. 24,

27570 Bremerhaven, Germany

${ }^{20}$ Earth and Atmospheric Sciences, Cornell University, Ithaca, NY 14850, USA

${ }^{21}$ Department of Earth and Atmospheric Sciences, University of Quebec in Montreal (UQAM), Montreal, QC, H3C 3P8, Canada

${ }^{22}$ Institute for Marine and Antarctic Studies, Uinversity of Tasmania, Hobart, Tasmania 7001, Australia

${ }^{23}$ Department of Earth Sciences, Vrije Universiteit Amsterdam, De Boelelaan 1085, 1081HV Amsterdam, the Netherlands

${ }^{24}$ Department of Natural Sciences and Environmental Health, University College of Southeast Norway, 3800 B $\varnothing$ i Telemark, Norway 
${ }^{25}$ Department of Physical Geography, Stockholm University, 10691 Stockholm, Sweden

Correspondence to: Bette L. Otto-Bliesner (ottobli@ucar.edu)

Received: 3 November 2016 - Discussion started: 28 November 2016

Revised: 20 July 2017 - Accepted: 21 August 2017 - Published: 7 November 2017

\begin{abstract}
Two interglacial epochs are included in the suite of Paleoclimate Modeling Intercomparison Project (PMIP4) simulations in the Coupled Model Intercomparison Project (CMIP6). The experimental protocols for simulations of the mid-Holocene (midHolocene, 6000 years before present) and the Last Interglacial (lig127k, 127000 years before present) are described here. These equilibrium simulations are designed to examine the impact of changes in orbital forcing at times when atmospheric greenhouse gas levels were similar to those of the preindustrial period and the continental configurations were almost identical to modern ones. These simulations test our understanding of the interplay between radiative forcing and atmospheric circulation, and the connections among large-scale and regional climate changes giving rise to phenomena such as land-sea contrast and highlatitude amplification in temperature changes, and responses of the monsoons, as compared to today. They also provide an opportunity, through carefully designed additional sensitivity experiments, to quantify the strength of atmosphere, ocean, cryosphere, and land-surface feedbacks. Sensitivity experiments are proposed to investigate the role of freshwater forcing in triggering abrupt climate changes within interglacial epochs. These feedback experiments naturally lead to a focus on climate evolution during interglacial periods, which will be examined through transient experiments. Analyses of the sensitivity simulations will also focus on interactions between extratropical and tropical circulation, and the relationship between changes in mean climate state and climate variability on annual to multi-decadal timescales. The comparative abundance of paleoenvironmental data and of quantitative climate reconstructions for the Holocene and Last Interglacial make these two epochs ideal candidates for systematic evaluation of model performance, and such comparisons will shed new light on the importance of external feedbacks (e.g., vegetation, dust) and the ability of state-of-the-art models to simulate climate changes realistically.
\end{abstract}

\section{Introduction}

The modeling of paleoclimate, using physically based tools, has long been used to understand and explain past environmental and climate changes (Kutzbach and Street-Perrott, 1985), and is increasingly seen as a strong out-of-sample test of the models that are used for the projection of future climate changes (Braconnot et al., 2012; Harrison et al., 2014,
2015; Schmidt et al., 2014). The Paleoclimate Modelling Intercomparison Project (PMIP) has served to coordinate paleoclimate experiments and data-model comparisons for several decades (Braconnot et al., 2007a, b, 2012; Joussaume and Taylor, 1995; Joussaume et al., 1999), and now spearheads the paleoclimate contribution to the current phase of the Coupled Model Intercomparison Project (CMIP6, Eyring et al., 2016).

This paper is part of a suite of five documenting the PMIP4 contributions to CMIP6. Kageyama et al. (2016) provide an overview of the five selected time periods and the experiments. More specific information is given in the contributions for the last millennium (past1000) by Jungclaus et al. (2017), for the last glacial maximum (lgm) by Kageyama et al. (2017), for the mid-Pliocene warm period (midPliocene-eoi400) by Haywood et al. (2016), and the present paper the mid-Holocene (midHolocene) and the previous interglacial (lig127k). PMIP4 has adopted the CMIP6 categorization where the highest-priority experiments are classified as Tier 1 , whereas additional sensitivity experiments or dedicated studies are Tier 2 or Tier 3 . The standard experiments for the five periods are all ranked Tier 1 . Tier 2 and 3 experiments absolutely require the corresponding Tier 1 experiment for their analysis, so the groups must perform the Tier 1 experiment first. Modeling groups are not obliged to run all PMIP4-CMIP6 experiments. It is mandatory, however, for all participating groups to run at least one of the experiments that were run in previous phases of PMIP (i.e., midHolocene or lgm).

The two experiments described here focus on comparing the most recent interglacial epochs and specifically the current interglacial (the Holocene) and the previous interglacial (the Last Interglacial, LIG) periods (Fig. 1). These two experiments are of interest because they examine the response of the climate system to relatively simple changes in forcing compared to present. The main difference in forcing from present was in the latitudinal and seasonal distribution of incoming solar radiation (insolation) caused by known changes in the Earth's orbit; greenhouse gas (GHG) concentrations were similar to those of the preindustrial period and the continental configurations were also very similar to modern ones. Differences in orbital configuration between the two interglacial periods (Berger, 1978) mean that the insolation changes are stronger in the LIG than in the Holocene, but the observational basis for evaluating model simulations is more extensive in the Holocene than the LIG because of preserva- 

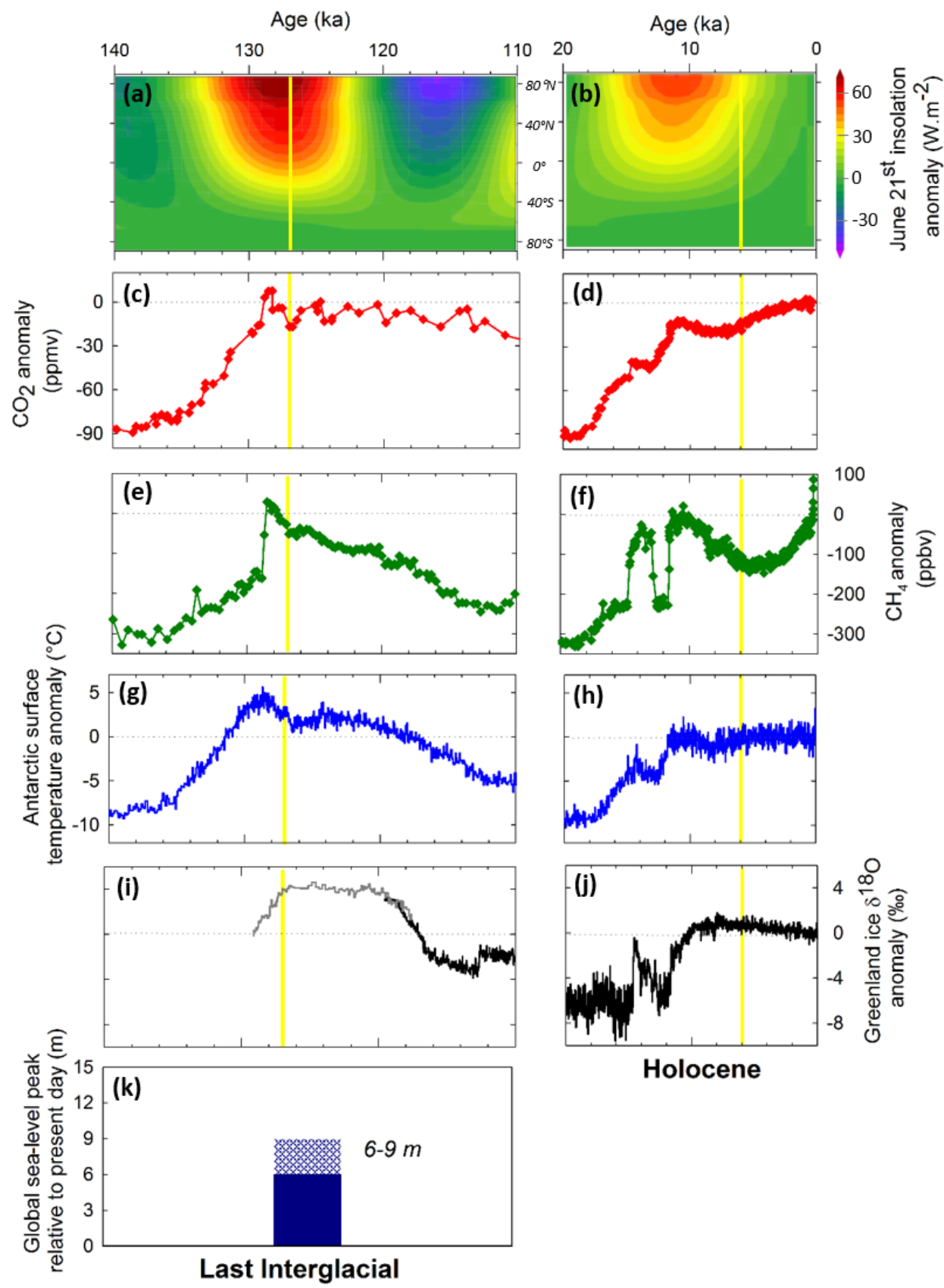

Figure 1. Forcing and climatic records across the Last Interglacial (LIG, left) and the Holocene (right). Records are displayed in panels (a) to (j) as anomalies relative to their average value of the last 1000 years. (a) and (b): 21 June insolation across latitudes; (c) and (d): atmospheric $\mathrm{CO}_{2}$ concentration (Siegenthaler et al., 2005; Schneider et al., 2013; Monnin et al., 2001, 2004); (e) and (f): atmospheric $\mathrm{CH}_{4}$ concentration (Loulergue et al., 2008); (g) and (h): Antarctic surface air temperature reconstruction (Jouzel et al., 2007); (i) and (j): Greenland ice $\delta^{18} \mathrm{O}$ : from the NEEM ice core (NEEM Community Members, 2013) in dark grey and from the NGRIP ice core (NorthGRIP Community Members, 2004) in black. Note that NEEM ice $\delta^{18} \mathrm{O}$ is shifted by $+2 \%$. (k) LIG maximum global mean sea level (GMSL) relative to the present day; uncertainties in the amplitude are indicated by the shading (see Dutton et al., 2015a, for a review). Time of maximum varies between reconstructions. No significant sea-level variations are reported throughout the Holocene compared to the present day. NGRIP ice $\delta^{18} \mathrm{O}$ is displayed on the GICC05 annual layer-counted timescale (Svensson et al., 2008) over the last $20 \mathrm{ka}$ and on the AICC2012 chronology (Bazin et al., 2013; Veres et al., 2013) across the 119-110 ka time interval. All other ice core records are displayed on the AICC2012 chronology, which is coherent, by construction with the GICC05 timescale over the last $60 \mathrm{ka}$ (Bazin et al., 2013; Veres et al., 2013). Vertical yellow lines indicate 127 and $6 \mathrm{ka}$, the time intervals chosen to run the coordinated PMIP4-CMIP6 lig127k and midHolocene simulations. 
tion issues. Taken together, these two interglacial periods are good test cases of our mechanistic understanding of the interplay between radiative forcing and atmospheric circulation, and opportunities to examine connections among large-scale and regional climate changes which give rise to phenomena such as land-sea contrast and high-latitude amplification of temperature changes, the regulation of atmospheric $\mathrm{CO}_{2}$ and biogeochemical cycles, and the waxing and waning of the monsoons.

The Tier 1 interglacial experiments for CMIP6 are timeslice (or equilibrium) experiments at 6000 and 127000 years before present (where present is defined as 1950), hereafter referred to as $6 \mathrm{ka}$ (midHolocene) and $127 \mathrm{ka}$ (lig127k). The mid-Holocene interval has been the focus for model simulations, model-model comparisons, paleodata synthesis, and model-data comparison since the beginning of PMIP, and this work has contributed to model evaluation and understanding of climate change in the last three major assessments of the Intergovernmental Panel on Climate Change (Flato et al., 2013; Folland et al., 2001; Hegerl et al., 2007; Jansen et al., 2007; Masson-Delmotte et al., 2013). The changes in insolation are characterized by enhanced seasonal contrast in the Northern Hemisphere (NH) (and reduced seasonal contrast in the Southern Hemisphere, SH), giving rise to warmer $\mathrm{NH}$ summers and a significant enhancement of the NH monsoons (COHMAP Members, 1988; Hély et al., 2014; Lezine et al., 2011; Saraswat et al., 2013; Tierney et al., 2017). Systematic benchmarking against pollen-based reconstructions of climate variables and lake-level-based waterbalance reconstructions (Braconnot et al., 2007b, 2012; Coe and Harrison, 2002; Harrison et al., 1998, 2014, 2015) has highlighted the fact that climate models persistently underestimate changes in the monsoon precipitation and produce too much continental drying (Harrison et al., 2015).

Given the long history of coordinated model experiments for $6 \mathrm{ka}$, this period allows us to assess whether there is an improvement in the ability of models to reproduce a climate state different from the modern one. For this reason, the Tier 1 midHolocene experiment is one of two possible "entry cards" for PMIP simulations in CMIP6 (Table 1): all modeling groups contributing to PMIP4-CMIP6 must perform either the midHolocene experiment or a simulation of the Last Glacial Maximum (Kageyama et al., 2016).

Although the LIG (129 to $116 \mathrm{ka}$ ) was discussed in the First Assessment Report of the IPCC (Folland et al., 1990), it gained more prominence in the IPCC Fourth and Fifth Assessment (AR4 and AR5) because of reconstructions highlighting that global mean sea level was at least $5 \mathrm{~m}$ higher (but probably no more than $10 \mathrm{~m}$ higher) than present for several thousand years (Dutton et al., 2015a; Jansen et al., 2007; Masson-Delmotte et al., 2013). Thus the LIG is recognized as an important period for testing our knowledge of climate-ice-sheet interactions in warm climate states. However, the ensemble of LIG simulations examined in the AR5 (Masson-Delmotte et al., 2013) was not wholly consistent: the orbital forcing and GHG concentrations varied between the simulations. While it has been suggested that differences in regional temperatures between models might reflect differences in cryosphere feedback strength (Yin and Berger, 2012; Otto-Bliesner et al., 2013) or differences in the simulation of the Atlantic Meridional Overturning Circulation (AMOC) (Bakker et al., 2013; Masson-Delmotte et al., 2013), differences between models could also have arisen because of differences in the experimental protocols. Furthermore, the LIG simulations were mostly made with older and/or lowerresolution versions of the models than were used for future projections, making it more difficult to use the results to assess model reliability (Lunt et al., 2013). The Tier 1 lig127k experiment (Table 1) is designed to address the climate responses to stronger orbital forcing than the midHolocene experiment using the same state-of-the-art models and following a common experimental protocol. It will provide a basis to address the linkages between ice sheets and climate change in collaboration with the Ice Sheet Model Intercomparison Project for CMIP6 (ISMIP6) (Nowicki et al., 2016).

The midHolocene and lig127k experiments are starting points for examining interglacial climates. A number of other experiments are proposed in the current phase of PMIP (PMIP4) to facilitate diagnosis of these Tier 1 experiments. The Tier 2 simulations will include sensitivity experiments to examine the impact of uncertainties in boundary conditions and the role of feedbacks in modulating the response to orbital forcing. Ocean, vegetation, and dust feedbacks, and the synergies between them, have been a focus in previous phases of PMIP (Braconnot et al., 1999; Dallmeyer et al., 2010; Otto et al., 2009; Wohlfahrt et al., 2004), and this allows us to design simple experimental protocols to compare the strength of these feedbacks in different climate models. Simulations with prescribed but adjusted vegetation cover will be a major focus for both the Holocene and LIG in PMIP4, and comparison of these simulations with ESM simulations that include dynamic vegetation will allow exploration of the magnitude of land-surface biases in these latter models. Changes in vegetation and land-surface hydrology are an important control on dust emissions (Tegen et al., 2002; Engelstädter et al., 2003), which can affect the strength of the West African Monsoon (Konare et al., 2008; Pausata et al., 2016). The examination of the dust feedback will be a new focus in PMIP4. In addition, the LIG provides an ideal opportunity to examine the role of cryosphere feedbacks through sensitivity experiments, which will be a focus of additional experiments associated with both the Holocene and the LIG. One such feedback is the release of freshwater into the ocean and the role of such freshwater forcing in generating more abrupt climate changes than would be expected for the smoothly varying changes in insolation forcing during an interglacial (Goelzer et al., 2016a; Luan et al., 2015; Stone et al., 2016). Understanding the role of feedbacks in general in the generation of abrupt climate changes, and the need to understand the relationship between mean climate changes 
Table 1. Forcings and boundary conditions. More details can be found in the section numbers indicated in parentheses.

\begin{tabular}{|c|c|c|c|}
\hline & $1850 \mathrm{CE}$ (DECK piControl) ${ }^{1}$ & $6 \mathrm{ka}(\text { midHolocene })^{2}$ & $127 \mathrm{ka}(\operatorname{lig} 127 k)^{2}$ \\
\hline Orbital parameters (Sect. 2.1) & CMIP DECK piControl & & \\
\hline Eccentricity & 0.016764 & 0.018682 & 0.039378 \\
\hline Obliquity (degrees) & 23.459 & 24.105 & 24.040 \\
\hline Perihelion - 180 & 100.33 & 0.87 & 275.41 \\
\hline Vernal equinox & Fixed to noon on 21 March & Fixed to noon on 21 March & Fixed to noon on 21 March \\
\hline \multicolumn{4}{|l|}{ Greenhouse gases (Sect. 2.2) } \\
\hline Carbon dioxide (ppm) & 284.3 & 264.4 & 275 \\
\hline Methane (ppb) & 808.2 & 597 & 685 \\
\hline Nitrous oxide (ppb) & 273.0 & 262 & 255 \\
\hline Other GHGs & CMIP DECK piControl & 0 & 0 \\
\hline Solar constant $\left(\mathrm{W} \mathrm{m}^{-2}\right)$ (Sect. 2.1$)$ & TSI: 1360.747 & Same as piControl & Same as piControl \\
\hline Paleogeography (Sect. 2.3) & Modern & Same as piControl & Same as piControl \\
\hline Ice sheets (Sect. 2.3) & Modern & Same as piControl & Same as piControl \\
\hline Vegetation (Sect. 2.4) & CMIP DECK piControl & $\begin{array}{l}\text { Prescribed or interactive as } \\
\text { in piControl }\end{array}$ & $\begin{array}{l}\text { Prescribed or interactive as } \\
\text { in piControl }\end{array}$ \\
\hline Aerosols (Sect. 2.5): dust, volcanic, etc. & CMIP DECK piControl & $\begin{array}{l}\text { Prescribed or interactive as } \\
\text { in piControl }\end{array}$ & $\begin{array}{l}\text { Prescribed or interactive as } \\
\text { in piControl }\end{array}$ \\
\hline
\end{tabular}

\footnotetext{
${ }^{1}$ More information on the CMIP DECK piControl and CMIP6 historical protocols can be found in the Geoscientific Model Development Special Issue on the Coupled Model Intercomparison Project Phase 6 (CMIP6) Experimental Design and Organization and at http://www.wcrp-climate.org/wgcm-cmip/wgcm-cmip6.
}

2 Data sets for midHolocene and lig127k are available on the PMIP4 web page: https://pmip4.lsce.ipsl.fr/doku.php/exp_design:index.

and short-term (annual to multi-decadal) climate variability, leads naturally to a desire to simulate the transient behavior of the climate system - and such transient experiments are proposed for both the Holocene and LIG time periods. New results have highlighted the possibility of using reconstruction of past interannual variability from corals and mollusc shells to assess the Holocene-simulated changes in variability at the scale of the tropical Pacific Ocean (Emile-Geay et al., 2016). Groups are also encouraged to run their models with an active land and ocean carbon cycle to assess terrestrial and ocean carbon storage and differences between the two interglacial periods.

The aim of this paper is to present and explain the experimental designs for both the PMIP4-CMIP6 Tier 1 interglacial experiments, and for associated Tier 2 and Tier 3 sensitivity and transient experiments. Section 2 describes and discusses the PMIP4-CMIP6 midHolocene Tier 1/entry card and lig127k Tier 1 simulations. Section 3 describes Tier 2 and Tier 3 PMIP4 sensitivity studies that can be carried out to diagnose these Tier 1 simulations. Section 4 briefly describes the paleodata resources, which can be used to evaluate the simulations.

\section{Experimental design for the Tier 1 PMIP4-CMIP6 midHolocene and lig127k simulations}

The core or Tier 1 experiments for the Holocene and the LIG are the midHolocene and lig127k simulations. The CMIP DECK (Diagnostic, Evaluation and Characterization of Klima) piControl for $1850 \mathrm{CE}$ and the CMIP6 historical experiment (see Eyring et al., 2016, for a description of these experiments) are the reference simulations to which the paleo-experiments will be compared. Thus, the paleoexperiments must use the same model components and follow the same protocols for implementing external forcings as are used in the piControl and historical simulations. The midHolocene simulation is one of the PMIP entry cards in the PMIP4-CMIP6 experiments, which means that groups who run the $l i g 127 \mathrm{k}$ simulation must also run either the midHolocene or the lgm (Last Glacial Maximum) experiment (Kageyama et al., 2016). The boundary conditions for the midHolocene, lig127k, and piControl experiments are given in Table 1, and more detailed information is given below.

\subsection{Orbital configuration, solar constant, and insolation anomalies}

Earth's orbital parameters (eccentricity, longitude of perihelion, and obliquity) should be prescribed following Berger and Loutre (1991). These parameters affect the seasonal and latitudinal distribution and magnitude of solar energy re- 
ceived at the top of the atmosphere and, in the case of obliquity, the annual mean insolation at any given latitude (Berger and Loutre, 1991). The DECK piControl simulations are to use the orbital parameters appropriate for $1850 \mathrm{CE}$ (Table 1) (Eyring et al., 2016), when perihelion occurs close to the boreal winter solstice. The exact date slightly varies depending on the internal model calendar and the number of days used to define a year. Because of this and the fact that the length of the seasons varies as a function of precession and eccentricity (Joussaume and Braconnot, 1997), the vernal equinox must be set to noon on 21 March in all the simulations (piControl, midHolocene, and lig127k). The orbit at $6 \mathrm{ka}$ was characterized by an eccentricity of 0.018682 , similar to $1850 \mathrm{CE}$ (Table 1). Obliquity was larger $\left(24.105^{\circ}\right)$ and perihelion at $6 \mathrm{ka}$ occurred near the boreal autumn equinox. The orbit at $127 \mathrm{ka}$ was characterized by larger eccentricity than at $1850 \mathrm{CE}$, with perihelion occurring close to the boreal summer solstice (Fig. 2). The tilt of the Earth's axis was maximal at $131 \mathrm{ka}$ and remained higher than in $1850 \mathrm{CE}$ through $125 \mathrm{ka}$; obliquity at $127 \mathrm{ka}$ was $24.04^{\circ}$ (Table 1). The different orbital configurations for the midHolocene and lig $127 \mathrm{k}$ result in different seasonal and latitudinal distribution of top-of-atmosphere insolation compared to the DECK piControl (Fig. 3). Both time periods show large positive insolation anomalies during boreal summer. July-August anomalies between 40 and $50^{\circ} \mathrm{N}$ reach about $55-60 \mathrm{~W} \mathrm{~m}^{-2}$ at $127 \mathrm{ka}^{2}$ and $25 \mathrm{~W} \mathrm{~m}^{-2}$ at $6 \mathrm{ka}$. The higher obliquity at 127 and $6 \mathrm{ka}$ contributes to a small but positive annual insolation anomaly compared to the preindustrial at high latitudes in both hemispheres and a slight insolation reduction in the tropics in the annual mean. The global difference in insolation forcing between the interglacial experiments and the preindustrial is negligible.

The solar constant prescribed for the midHolocene and lig127k simulations is the same as in the DECK piControl simulation, which is fixed at the mean value for the first two solar cycles of the historical simulation (i.e., 1850-1871) (Eyring et al., 2016). This value $\left(1360.7 \mathrm{~W} \mathrm{~m}^{-2}\right)$ is lower than the value for the solar constant used by some models in PMIP3 (1365 $\mathrm{W} \mathrm{m}^{-2}$ ) and this leads to a global reduction of incoming solar radiation compared to the PMIP3 experiments (Fig. 4). The slight differences in orbital parameters between the $1850 \mathrm{CE}$ reference periods to be used for PMIP4-CMIP6 and the 1950 CE reference used for PMIP3 leads to seasonal differences in forcing with a slight decrease in boreal spring and increase in boreal autumn. The combination of the two factors leads to an overall reduction: the largest reduction occurs in boreal spring and is about $1.6 \mathrm{~W} \mathrm{~m}^{-2}$ between $10^{\circ} \mathrm{S}$ and $40^{\circ} \mathrm{N}$.

\subsection{Greenhouse gases}

Ice-core records from Antarctica and Greenland provide measurements of the well-mixed GHGs: $\mathrm{CO}_{2}, \mathrm{CH}_{4}$, and $\mathrm{N}_{2} \mathrm{O}$ (Fig. 1). These measurements are given as mole fractions in dry air and are noted as parts per million (ppm) or parts per
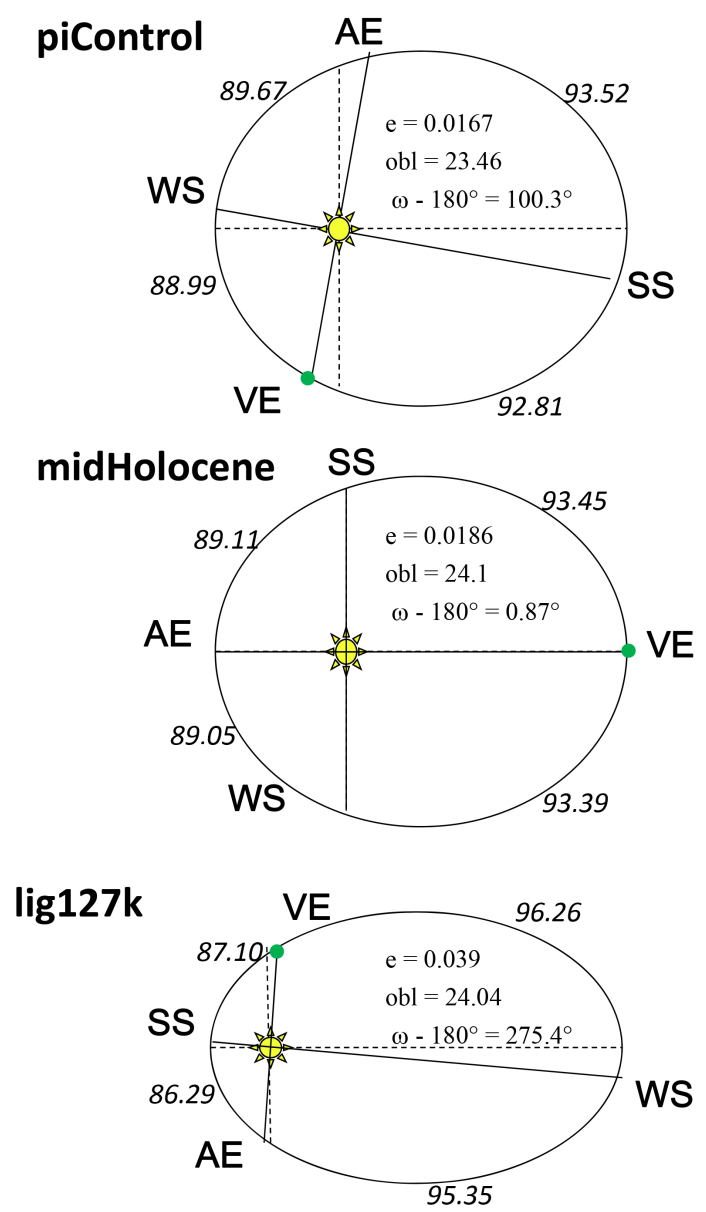

Figure 2. Orbital configurations for the piControl, midHolocene, and lig127k experiments. Note that the aspect ratio between the two axes of the ellipse has been magnified to better highlight the differences between the periods. However, the change in ratio between the different periods is proportional to the real values. In these graphs VE stands for vernal equinox, SS for summer solstice, $\mathrm{AE}$ for autumnal equinox, and WS for winter solstice. The numbers along the ellipse are the number of days between solstices and equinoxes.

billion (ppb), respectively. For simplicity, we use the term "concentration" for these GHG levels. By 6 and $127 \mathrm{ka}$, the concentrations of atmospheric $\mathrm{CO}_{2}$ and $\mathrm{CH}_{4}$ had increased from their respective levels during the previous glacial periods, the Last Glacial Maximum and the penultimate glaciation, to values comparable to preindustrial levels.

midHolocene. In PMIP4-CMIP6, we use a revised version of an earlier trace gas reconstruction (Joos and Spahni, 2008). The $\mathrm{CO}_{2}$ concentration for the mid-Holocene is derived from ice-core measurements from Dome C (Monnin et al., 2001, 2004) and dated using the AICC2012 age scale (Veres et al., 2013). A smoothing spline (Bruno and Joos, 1997; Enting, 1987) with a nominal cut-off period of 3000 years was used to produce a continuous $\mathrm{CO}_{2}$ record. This yields a $\mathrm{CO}_{2}$ concentration of $264.4 \mathrm{ppm}$ at 

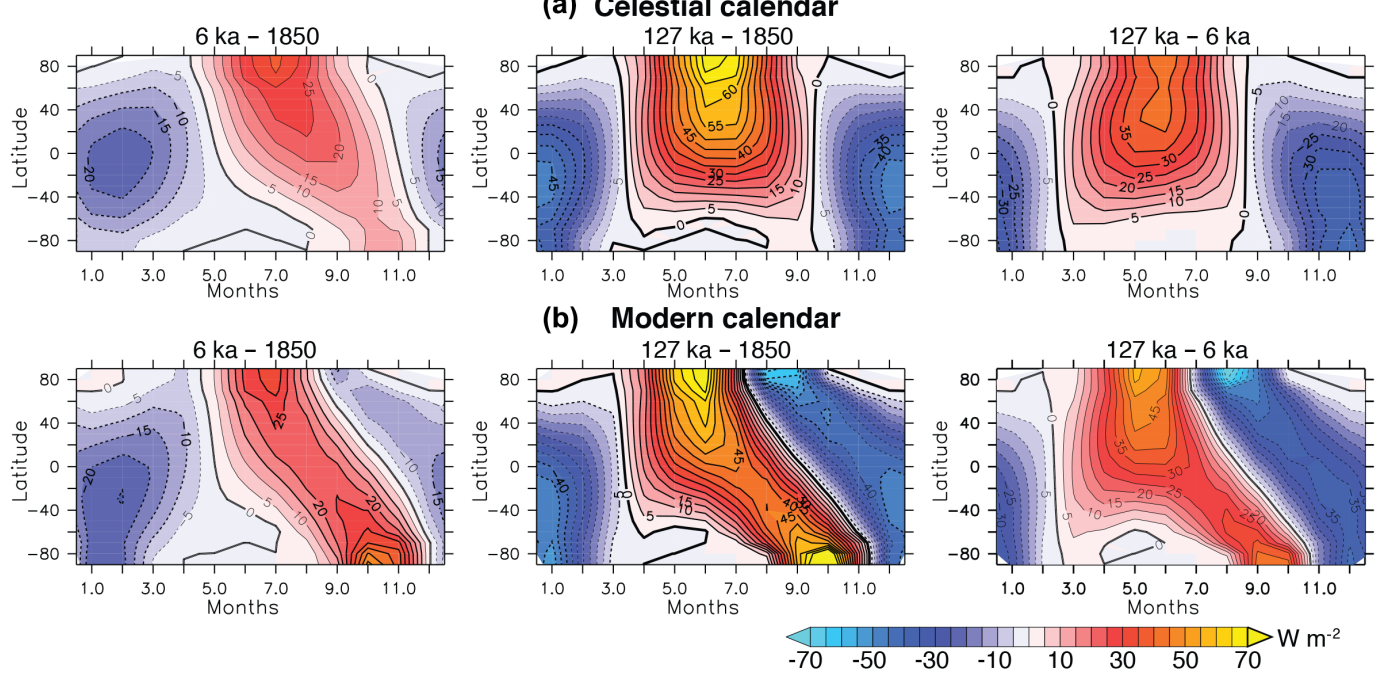

Figure 3. Latitude-month insolation anomalies (6 ka-1850, $127 \mathrm{ka}-1850,127-6 \mathrm{ka})$ computed using either the celestial calendar (a) or the modern calendar (b), with vernal equinox on 21 March at noon, to compute monthly averages $\left(\mathrm{W} \mathrm{m}^{-2}\right)$.

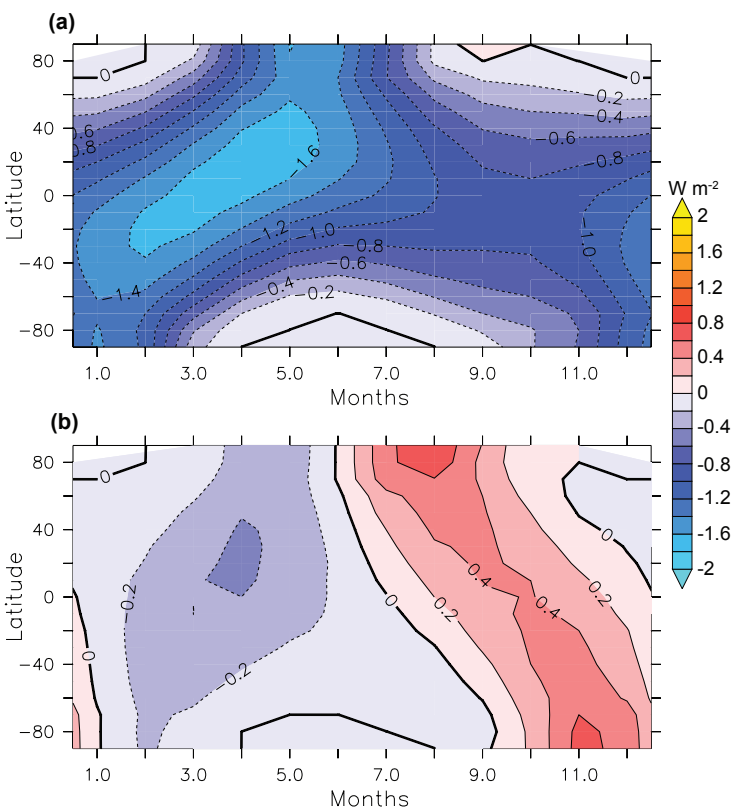

Figure 4. Difference in incoming solar radiation at the top of the atmosphere $\left(\mathrm{W} \mathrm{m}^{-2}\right)$ between the PMIP4 and PMIP3 protocols, (a) considering the changes in Earth's orbital parameters between 1850 and 1950 and the reduction of the solar constant from 1365 to 1360.7 between these two PMIP phases and (b) only the changes in Earth's orbital parameters, assuming a solar constant of $1365 \mathrm{~W} \mathrm{~m}^{-2}$.

$6 \mathrm{ka}$. Methane has been measured in ice from Antarctic ice cores EPICA Dome C (Flückiger et al., 2002), EPICA Dronning Maud Land (EPICA Community Members, 2006) and Talos Dome (Buiron et al., 2011). For Greenland, methane data are from GRIP (Blunier et al., 1995; Chappellaz et al., 1997; Spahni et al., 2003), GISP2 (Brook, 2009), and GISP2D (Mitchell et al., 2013). Both are splined with a nominal cut-off period of 200 years. This results in a concentration of $574 \mathrm{ppb}$ for the Antarctic ice cores, representative of high-latitude Southern Hemisphere air, and of $620 \mathrm{ppb}$ for the Greenland ice cores, representative of the high-latitude Northern Hemisphere air, and an estimated global mean value of $597 \mathrm{ppb}$. The $\mathrm{N}_{2} \mathrm{O}$ data around $6 \mathrm{ka}$ are from a compilation of published data from EPICA Dome C (Flückiger et al., 2002; Spahni et al., 2005) and new, unpublished data measured at the University of Bern using ice from Greenland (NGRIP) and Talos Dome (TALDICE). The data are splined with a nominal cut-off period of 700 years and the resulting $\mathrm{N}_{2} \mathrm{O}$ concentration at $6 \mathrm{ka}$ is $262 \mathrm{ppb}$.

The realistic GHG concentrations used for the midHolocene PMIP4-CMIP6 experiment are different from those used in the PMIP3 experiments (Braconnot et al., 2012). The PMIP3 experiments were designed simply to examine the effects of changes in orbital forcing, and the $\mathrm{CO}_{2}$ concentrations were therefore kept the same as the value typically used in preindustrial experiments $(280 \mathrm{ppm})$, although other GHGs were prescribed from ice-core measurements. The use of realistic values for all the GHGs in the PMIP4CMIP6 midHolocene experiment may improve comparisons with paleoclimate reconstructions and will ensure that the midHolocene experiment is consistent with planned transient Holocene simulations (see Sect. 3). However, the reduction in $\mathrm{CO}_{2}$ concentration from 280 to $264.4 \mathrm{ppm}$ will reduce GHG forcing by about $0.3 \mathrm{~W} \mathrm{~m}^{-2}$ (Myhre et al., 1998), which translates to a difference in global mean surface air temperature of $-0.24^{\circ} \mathrm{C}$ when applying an equilibrium climate sensitivity of $3^{\circ} \mathrm{C}$ for a nominal doubling of $\mathrm{CO}_{2}$. Simulations with the IPSL model (Dufresne and co-authors, 


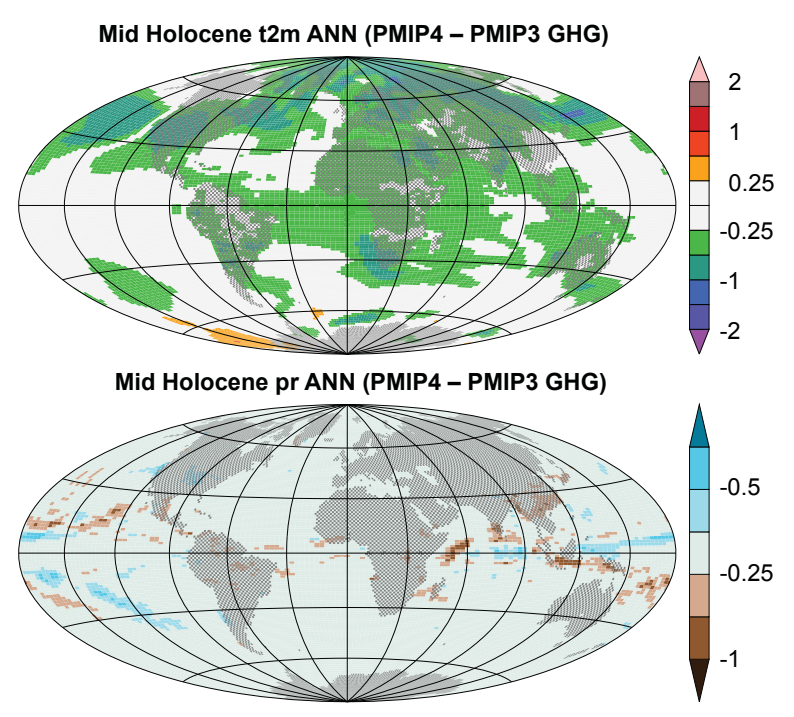

Figure 5. Impact of the changes in trace gases specified for $6 \mathrm{ka}$ between PMIP3 and PMIP4 on surface air temperature $\left({ }^{\circ} \mathrm{C}\right)$ and precipitation $\left(\mathrm{mm} \mathrm{d}^{-1}\right)$ as estimated with the IPSLCM5A model. Only significant values are plotted in colors.

2013) show that this change in the experimental protocol between PMIP3 and PMIP4-CMIP6 yields a global mean cooling of $0.24 \pm 0.04^{\circ} \mathrm{C}$, as expected, with regional differences of up to $0.5^{\circ} \mathrm{C}$ in parts of Eurasia and in South Africa (Fig. 5). Although these differences are small overall, they will need to be accounted for in comparisons between the PMIP4-CMIP6 midHolocene simulations and previous generations of PMIP 6 ka simulations.

lig 127k. The LIG GHG concentrations are available solely from Antarctic ice cores. $\mathrm{CO}_{2}$ concentrations can only be derived from Antarctic ice, because of potential in situ $\mathrm{CO}_{2}$ production in the Greenland ice sheet (Tschumi and Stauffer, 2000). We also do not have any reliable $\mathrm{CH}_{4}$ and $\mathrm{N}_{2} \mathrm{O}$ concentrations from Greenland in the LIG due to melt layers in the ice, as Greenland temperatures were significantly warmer at that time compared to the mean of the past millennium (Fig. 1) (NEEM Community Members 2013). For the lig 127k simulation (Table 1), we adopt mean values for 127.5-126.5 ka on the AICC2012 age scale (Bazin et al., 2013) from EPICA Dome C (Bereiter et al., 2015; Schneider et al., 2013) for $\mathrm{CO}_{2}$, from EPICA Dome $\mathrm{C}$ and EPICA Dronning Maud Land (Loulergue et al., 2008; Schilt et al., 2010a) for $\mathrm{CH}_{4}$, as well as from EPICA Dome $\mathrm{C}$ and Talos Dome (Schilt et al., 2010a, b) for $\mathrm{N}_{2} \mathrm{O}$. The atmospheric $\mathrm{CO}_{2}$ and $\mathrm{N}_{2} \mathrm{O}$ concentrations of $275 \mathrm{ppm}$ and $255 \mathrm{ppb}$, respectively, can be regarded as globally representative, while the mean ice core $\mathrm{CH}_{4}$ concentration (662 ppb) is representative of high-latitude Southern Hemisphere air. A global mean atmospheric $\mathrm{CH}_{4}$ concentration of $685 \mathrm{ppb}$ is adopted for $127 \mathrm{ka}$, thereby assuming the same difference ( $23 \mathrm{ppb})$ be- tween the global mean atmospheric $\mathrm{CH}_{4}$ and Antarctic ice core $\mathrm{CH}_{4}$ values as for the mid-Holocene.

\subsection{Paleogeography and ice sheets}

midHolocene. Several lines of evidence indicate that the ice sheets had their modern characteristics by the mid-Holocene, except in a few places such as the Baffin Islands (Carlson et al., 2008b; Clark et al., 2000). While the presence of a relic of the Laurentide ice sheet may be the origin of modeldata mismatches in the climate of eastern North America (Wohlfahrt et al., 2004), the effect is local and small. Cosmogenic surface exposure ages and threshold lake records (Carlson et al., 2014; Larsen et al., 2015; Sinclair et al., 2016) also suggest that by $6 \mathrm{ka}$, the Greenland ice sheet was similar in extent to present. The ice-sheet distribution and elevations, land-sea mask, continental topography and oceanic bathymetry should all be prescribed as the same as in piControl in the midHolocene simulation (Table 1).

lig $127 k$. Evidence for the evolution of the ice sheets during the LIG comes mainly from proximal marine records (Carlson and Winsor, 2012). The deposition of a detrital carbonate layer in the Labrador Sea, dated to around $128 \mathrm{ka}$ based on geomagnetic secular variation (Winsor et al., 2012), suggests that ice had retreated from Hudson Bay and is taken to indicate the final demise of the Laurentide ice sheet (Carlson, 2008; Nicholl et al., 2012). The disappearance of the Eurasian ice sheet is more difficult to constrain because either the proximal marine records lack benthic $\delta^{18} \mathrm{O}$ data or the benthic $\delta^{18} \mathrm{O}$ data show trends that are different from those of open ocean records during the LIG (Bauch, 2013). The cessation of deposition of ice-rafted debris (IRD) from the Eurasian ice sheet has been dated to between 128 and $126 \mathrm{ka}$ using $\delta^{18} \mathrm{O}$ (Risebrobakken et al., 2006). However, sea-level data (Dutton et al., 2015b) suggest that this ice sheet disappeared earlier and was likely gone by $\sim 127 \mathrm{ka}$. Proximal marine records of the Greenland ice sheet document a gradual retreat during the LIG, with minimum extent around $120 \mathrm{ka}$ (Carlson et al., 2008a; Colville et al., 2011; Stoner et al., 1995; Winsor et al., 2012). However, Greenland-sourced IRD reached a minimum similar to the Holocene before $\sim 127 \mathrm{ka}$ (Colville et al., 2011; Winsor et al., 2012).

The extent of the Antarctic ice sheet is not directly constrained by data proximal to the ice sheet at $127 \mathrm{ka}$. Given higher-than-present sea levels, the gradual retreat of the Greenland ice sheet, and the lack of other NH ice sheets, it seems likely that the Antarctic ice sheet was smaller than present by $\sim 127 \mathrm{ka}$ (Colville et al., 2011; Dutton et al., 2015a, b; Mercer, 1978). The existence of $\sim 250 \mathrm{ka} \mathrm{Mt}$. Erebus ash in the ANDRILL site in the Ross Sea could indicate a smaller-than-present West Antarctic ice sheet (WAIS) some time after $\sim 250 \mathrm{ka}$ (McKay et al., 2012). The ice-core record from Mount Moulton, West Antarctica, could be consistent with deglaciation of much of West Antarctica during the LIG, and likely at 130-126 ka (Steig et al., 2015). Standalone ice- 
sheet model simulations forced by ocean warming suggest the West Antarctic ice sheet to be a major contributor to LIG global mean sea-level rise, with contributions also coming from the marine-based portions of the East Antarctic ice sheet (DeConto and Pollard, 2016). Contributions are 6.0$7.5 \mathrm{~m}$ of the equivalent sea-level rise, which would explain the global mean sea level being at least $+6 \mathrm{~m}$ by $\sim 127 \mathrm{ka}$ (Dutton et al., 2015b). However, because of the difficulty in implementing ice-to-ocean changes for the WAIS and the uncertainties associated with dating the changes in the other ice sheets, the paleogeography of the lig $127 k$ simulation will be prescribed the same as in the DECK piControl simulation (Table 1). In view of the greater uncertainty associated with the prescription of ice sheets in the lig $127 k$ experiment, this aspect of the boundary conditions will be a major focus of sensitivity experiments (see Sect. 3).

\subsection{Vegetation}

There is abundant evidence for changes in vegetation distribution during the mid-Holocene and the LIG (Goni et al., 2005; Harrison and Bartlein, 2012; Hély et al., 2014; LIGA Members, 1991; Prentice et al., 2000). However, there is insufficient data coverage for many regions to be able to produce reliable global vegetation maps. Furthermore, given the very different levels of complexity in the treatment of vegetation properties, phenology and dynamics in the current generation of climate models, paleo-observations do not provide sufficient information to constrain their behavior in a comparable way. The treatment of natural vegetation in the midHolocene and lig $127 k$ simulations should therefore be the same as in the DECK piControl simulation. That is, depending on what is done in the DECK piControl simulation, vegetation should either be prescribed to be the same as in that simulation, or prescribed but with interactive phenology, or predicted dynamically (Table 1). Uncertainties related to the treatment of vegetation in the different simulations will be analyzed through sensitivity experiments (see Sect. 3).

\subsection{Aerosols: tropospheric dust and stratospheric volcanic}

Natural aerosols show large variations on glacial-interglacial timescales, with low aerosol loadings during interglacials compared to glacials, and during the peak of the interglacials compared to the present day (Albani et al., 2015; deMenocal et al., 2000; Kohfeld and Harrison, 2000; McGee et al., 2013). Atmospheric dust affects radiative forcing at a regional scale and can therefore affect precipitation and surface hydrology (Miller et al., 2004; Yoshioka et al., 2007), including the monsoons (Konare et al., 2008; Pausata et al., 2016; Vinoj et al., 2014), as well as moderate snow albedo feedbacks when sufficient dust is deposited (Krinner et al., 2006). While model simulations that are observationally constrained by a global compilation of dust records suggest that

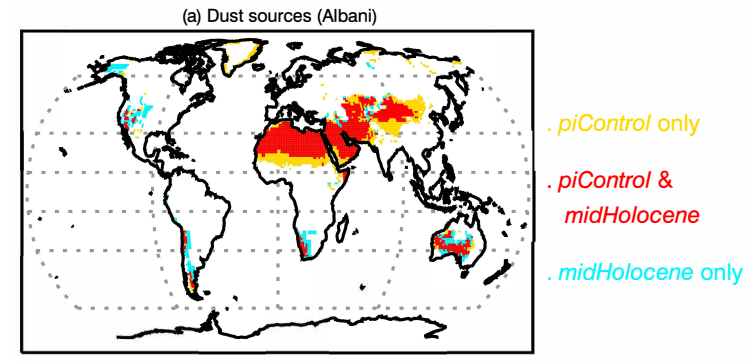

(b) midHolocene dust deposition flux (Albani)

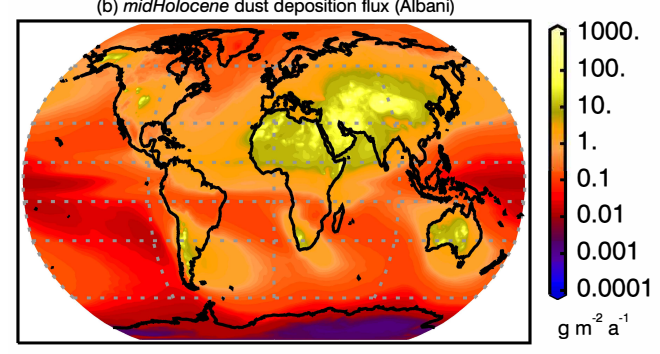

(c) midHolocene / piControl ratio in dust deposition

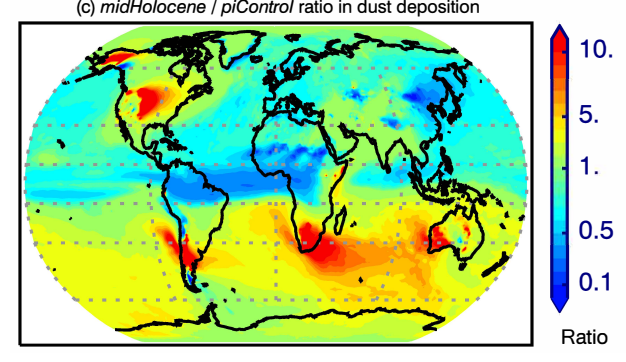

Figure 6. Maps of dust from observationally constrained simulations with the Community Climate System Model for the midHolocene (Albani et al., 2015). (a) Active sources for dust emissions for the midHolocene and the piControl (Albani et al., 2016). (b) Dust deposition $\left(\mathrm{g} \mathrm{m}^{-2}\right.$ year $\left.^{-1}\right)$ in the midHolocene. (c) Ratio of midHolocenelpiControl dust deposition.

the global dust budget was dominated by NH dynamics during the midHolocene as it is today, the total loading as well as regional patterns of dust loading were different (Albani et al., 2015). This motivates the inclusion of changes in dust loading in the midHolocene and lig127k simulations (Table 1, Fig. 6).

As in the case of vegetation, the implementation of changes in atmospheric aerosol in the midHolocene and lig127k simulations should follow the treatment used for the DECK piControl and historical simulations. Models with an interactive representation of dust should prescribe changes in soil erodibility or dust emissions to account for the changes in dust sources during the interglacials. Although the maps provided by PMIP for this purpose are for mid-Holocene conditions and from the only model simulation available (Albani et al., 2015), they should be used for both the midHolocene and lig127k simulations. For each model configuration, if atmospheric dust loading is prescribed in the DECK piControl and historical simulations, the midHolocene and lig127k simulations should use the 
three-dimensional monthly climatology of atmospheric dust mass concentrations or aerosol optical depths available from the same data-constrained simulations as the soil erodibility maps. Also available are data sets of the dust shortwave and longwave direct radiative forcing. If atmospheric dust loading is not represented in the DECK piControl and historical simulations, it should not be included in the midHolocene and lig $127 k$ simulations. The impact of dust on the radiation balance is sensitive to the optical properties prescribed (Perlwitz et al., 2001); it is uncertain how optical properties might change during interglacials (Potenza et al., 2016; Royer et al., 1983). Uncertainties in the protocol and in the interplay between dust and vegetation will be a focus of the analyses.

There is no observationally constrained estimate of the volcanic stratospheric aerosol for either the mid-Holocene or the LIG. The background volcanic stratospheric aerosol used in the CMIP6 DECK piControl should be used for the midHolocene and lig127k simulations. Other aerosols included in the DECK piControl should similarly be included in the midHolocene and lig127k simulations.

\subsection{Setup and documentation of simulations}

To provide initial conditions for the simulations, it is recommended that a spin-up simulation is performed departing from the CMIP6 piControl experiment. The length of this spin-up simulation will be model- and resource-dependent. However, it should be long enough to minimize at least surface climate trends.

The modeling groups are responsible for a comprehensive documentation of the model system and the experiments. Documentation should be provided via the ESDOC website and tools provided by CMIP6 (http://es-doc.org/) to facilitate communication with other CMIP6 projects. A PMIP4 special issue in GMD and Climate of the Past has been opened where the groups are encouraged to publish these documentations.

The documentation should include the following.

- The model version and specifications, like interactive vegetation or interactive aerosol modules.

- A link to the DECK experiments performed with this model version.

- Specification of the forcing data sets used and their implementation in the model. The provision of figures and tables giving monthly latitude insolation anomalies and daily incoming solar radiation at the top of the atmosphere (TOA) for 1 year should be provided because this allows the implementation of the most critical forcing to be checked.

- Information about the initial conditions and spin-up technique used.

- We request information on drift in key variables for a few hundred years at the end of the spin-up and the beginning of the actual experiment. These variables are
- globally and annually averaged SSTs;

- deep ocean temperatures (global and annual average over depths below $2500 \mathrm{~m}$ );

- deep ocean salinity (global and annual average over depths below $2500 \mathrm{~m}$ );

- top of atmosphere energy budget (global and annual average);

- surface energy budget (global and annual average);

- northern sea ice (annual average over the Northern Hemisphere);

- southern sea ice (annual average over the Southern Hemisphere);

- northern surface air temperature (annual average over the Northern Hemisphere);

- southern surface air temperature (annual average over the Southern Hemisphere);

- Atlantic Meridional Overturning Circulation (maximum overturning stream function in the North Atlantic basin between 0 and $80^{\circ} \mathrm{N}$ below $500 \mathrm{~m}$ depth); and

- carbon budget (if relevant).

\section{PMIP4-CMIP6 Tier 2 and Tier 3 simulations}

The selection of only two intervals, midHolocene and lig127k, for PMIP4-CMIP6 interglacial experiments is designed to maximize both the multi-model ensemble size and opportunities for model evaluation, since both periods have been the focus for data synthesis. However, this means that the experiments do not sample the diversity in the transient forcings and responses during the LIG and the Holocene. Although transient simulations for these two periods are included in the suite of PMIP4 simulations (see Sect. 3.5), there is utility in examining other interglacial climates using equilibrium experiments parallel to the midHolocene and lig127k simulations, particularly in order to provide additional samples of the response of the system to insolation forcing. Additional Tier 2 experiments - the end of the LIG (116 ka) and the early Holocene (9.5 ka) (see Sect. 3.1) - are proposed to address this.

Uncertainties in the boundary and initial conditions for the mid-Holocene and LIG mean that the PMIP4-CMIP6 midHolocene and lig127k simulations may not capture important feedbacks accurately. The major sources of uncertainty in the boundary conditions are the prescription of modern vegetation cover by some models, and the prescription of modern ice sheets in the lig127k simulation. Both sources of uncertainty can be addressed through Tier 2 sensitivity experiments (see Sect. 3.2, 3.3). The equilibrium experiments also do not address climate changes forced by the nonlinear behavior of ice-sheet-ocean coupling, or the possibility that 
such feedbacks could give rise to abrupt changes in climate superimposed on the more slowly varying insolation forcing during the Holocene and the LIG. This will be addressed through Tier 2 idealized simulations of specific freshwaterforcing events, specifically the Heinrich 11 event at the beginning of the LIG and the $8.2 \mathrm{ka}$ event during the Holocene (see Sect. 3.4). Understanding the interplay among different components of the Earth system in determining the long-term evolution of LIG and Holocene climate is the major goal of the proposed Tier 3 transient experiments (Sect. 3.5) to be carried out during PMIP4.

Further information and access to data sets are available on the PMIP4 website and will be updated during the course of the project (https://pmip4.lsce.ipsl.fr/doku.php/exp_design: index).

\subsection{Equilibrium response to alternative states of orbital forcing}

hol9.5k. The maximum expression of Holocene orbitally induced differences in TOA insolation forcing from present occurred during the early part of the Holocene, but the climate at this time was still affected by the presence of a relic of the Laurentide ice sheet (Carlson et al., 2008b). As a result, summer temperatures at mid to high latitudes were cooler than during the mid-Holocene (Carlson et al., 2008b; Renssen et al., 2009, 2012). The presence of the ice sheet delayed the response to insolation forcing in monsoon regions (Lezine et al., 2011; Marzin et al., 2013). It has also been suggested that the remnant ice sheet may have counteracted the reduction of ENSO variability in response to orbital forcing in the early Holocene (Carre et al., 2014; Luan et al., 2015). Protocols for early Holocene experiments were developed in previous phases of PMIP (PMIP2, PMIP3), and provide the basis for the proposed PMIP4 simulation for $9.5 \mathrm{ka}$. Since the phase of precession at $9.5 \mathrm{ka}$ is similar to that of $127 \mathrm{ka}$, this experiment provides a basis for examination of the similarities in seasonal changes between the two interglacials (Braconnot et al., 2008). Following the experimental protocol for the midHolocene simulation, orbital parameters should be changed following Berger and Loutre (1991). The extent and topography of the ice sheet should be prescribed using either ICE-6G or GLAC-1D, as proposed by the PMIP deglaciation working group (Ivanovic et al., 2016). GHG concentrations can also be prescribed from the last deglaciation experiment (Table 2).

lig116k. Continental ice-sheet growth and associated sealevel lowering started at $\sim 116 \mathrm{ka}$, marking the end of the LIG (Stirling et al., 1998). Simulations with climate models that include feedbacks among the atmosphere, ocean, land, and sea ice are able to simulate sufficient cooling to initiate ice-sheet growth when forced with the $116 \mathrm{ka}$ orbital conditions, reducing NH summer insolation (Herrington and Poulsen, 2012; Jochum et al., 2012). However, the result is sensitive to the atmospheric $\mathrm{CO}_{2}$ concentration used. To test the ability of the CMIP6 and PMIP4 models to simulate glacial inception, we propose a sensitivity experiment using orbital parameters for $116 \mathrm{ka}$ (lig116k). The $\mathrm{CO}_{2}$ concentration should be prescribed as $273 \mathrm{ppm}$ (Bereiter et al., 2015; Schneider et al., 2013). All other forcings and boundary conditions will remain the same as the lig127k simulation (Table 2).

\subsection{Sensitivity to prescribed vegetation}

Except in the case of models with dynamic vegetation, the midHolocene and lig127k simulations will be run with prescribed preindustrial vegetation cover because of the lack of a comprehensive and reliable global data set of vegetation for the two periods. However, pollen and macro-fossil evidence shows that boreal forest extended farther north than today in the mid-Holocene (Bigelow and al., 2003; Prentice et al., 2000; Binney et al., 2017) and, except in Alaska and central Canada, extended to the Arctic coast during the LIG (Edwards et al., 2003; LIGA, 1991; Lozhkin and Anderson, 1995). Pollen and other biogeographical/geomorphological and paleohydrological evidence also indicates northward extension of vegetation into modern-day desert areas, particularly in northern Africa, both in the mid-Holocene (Drake et al., 2011; Hély et al., 2014; Larrasoana et al., 2013; Lezine et al., 2011; Prentice et al., 2000; Tierney et al., 2017) and during the maximum phase of the LIG (Castaneda et al., 2009; Hooghiemstra et al., 1992). Given the impact of increased woody cover on albedo and evapotranspiration, these vegetation changes should have profound impacts on the surface energy and water budgets and may help to explain mismatches between simulated and reconstructed high-latitude (Muschitiello et al., 2015) and monsoon climates (Braconnot et al., 1999; Claussen and Gayler, 1997; Pausata et al., 2016) in both time periods.

We propose sensitivity experiments for the midHolocene and $l i g 127 \mathrm{k}$ to explore the feedbacks between vegetation and climate. Vegetation cover at the NH high latitudes should be changed from tundra to boreal forest and the Sahara replaced by evergreen shrub to $25^{\circ} \mathrm{N}$ and savanna/steppe poleward of $25^{\circ} \mathrm{N}$. Ideally, these regional changes should be made separately in order to diagnose the interaction between highlatitude and low-latitude climates, and a third experiment could be made implementing both changes. In each experiment, all other boundary conditions should be implemented as in the baseline midHolocene and lig 127k simulations (Table 2).

Sensitivity experiments will also be required to characterize the uncertainties related to the prescription of dust fields in the mid-Holocene and LIG simulations, but it is difficult to anticipate the form of such experiments until the Tier 1 experiments are diagnosed. A first step could be to investigate the vegetation feedback on emission in simulations with interactive dust exploiting the vegetation sensitivity analyses. 
Table 2. Summary of PMIP4 Tier 2 and Tier3 sensitivity simulations complementing PMIP4/CMIP6 Tier 1 interglacial experiments. More details can be found in the section numbers indicated in parentheses.

PMIP4-CMIP6 sensitivity experiments: Tier 2 simulations

\begin{tabular}{lcc}
\hline Experiments & Holocene & Last Interglacial \\
\hline Orbital forcing and trace gases (Sect. 3.1) & hol9.5k: Early Holocene & lig116k: Glacial inception \\
& - Orbital: $9.5 \mathrm{ka}^{1}$ & $-{\text { Orbital: } 116 \mathrm{ka}^{2}}^{2}$ \\
& - Ice sheet: ICE-6G or GLAC-1D & $-\mathrm{CO}_{2}: 273 \mathrm{ppm}$ \\
& reconstruction & \\
& - GHG: same as for the deglaciation $^{3}$ & - Other forcings and boundary condi- \\
& tions: as for lig $127 k$
\end{tabular}

midHolocene-veg

- prescribed boreal forests in the Arctic and shrub/savanna over the Sahara (together and in turn) lig127k-veg

- prescribed boreal forests in the Arctic and shrub/savanna over the Sahara (together and in turn)
Sensitivity to ice sheet (Sect. 3.3)

\author{
hol8. $2 \mathrm{k}: 8.2 \mathrm{ka}$ event \\ - Meltwater flux of 2.5 Sv for 1 year \\ added to the Labrador Sea followed \\ by $0.13 \mathrm{~Sv}$ for 99 years \\ - Other forcings and boundary condi- \\ tions: as for hol9.5k \\ - Initial state: hol9.5k simulation
}

lig127k-ais and lig127k-gris

- Antarctic ice sheet at its minimum LIG extent

- Greenland ice sheet at its minimum LIG extent

lig127k-H11: Heinrich 11 meltwater event

- Meltwater flux of 0.2 Sv to the North Atlantic between 50 and $70^{\circ} \mathrm{N}$ for 1000 years

- Other forcings and boundary conditions: as for lig $127 k$

- Initial state: lig127k simulation

PMIP4-CMIP6 sensitivity experiments: Tier 3 simulations

Transient simulations (Sect. 3.5)

(Note: exploratory and flexible setup)

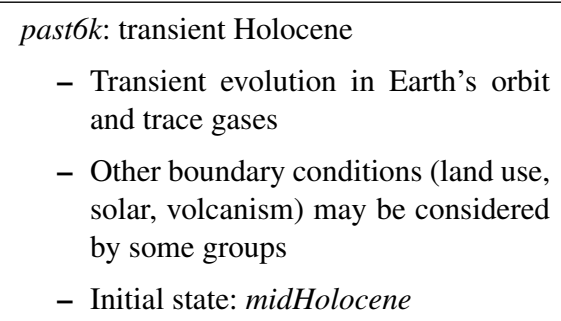

- Transient evolution in Earth's orbit and trace gases

- Other boundary conditions (land use, solar, volcanism) may be considered by some groups

- Initial state: midHolocene

lig127to121k: transient LIG

- Transient evolution in Earth's orbit and trace gases

- Other boundary conditions (ice sheets) may be considered by some groups

- Initial state: lig127k

\footnotetext{
${ }^{1}$ Orbital parameters for $9.5 \mathrm{ka}$ : eccentricity $=0.0193$, obliquity $=24.23$, perihelion $-180=303$.

2 Orbital parameters for $116 \mathrm{ka}$ : eccentricity $=0.0414$, obliquity $=22.49$, perihelion $-180=94.17$.

3 Ivanovic et al. (2016); available on the PMIP4 web page
}

\subsection{Sensitivity to prescribed ice sheets}

The midHolocene and lig127k simulations will be run with prescribed modern ice sheets and paleogeography. However, it is highly likely that the Antarctic ice sheet was smaller than present by $\sim 127 \mathrm{ka}$, most probably because of the dis- appearance of the WAIS, and that the Greenland ice sheet was reduced in extent compared to present. Given that only about 3-4 m sea-level rise is covered by contributions from ocean thermal expansion (McKay et al., 2011), land-based glaciers (Marzeion et al., 2012), and melting of the Green- 
land ice sheet (NEEM Community Members, 2013; MassonDelmotte et al., 2013), the remaining sea-level rise is most likely to be linked to a mass loss from the Antarctic ice sheet. We propose a sensitivity experiment (lig127k-ais) to test the impact of a smaller-than-present Antarctic ice sheet, using a reduced ice-sheet configuration obtained from offline simulations with their own models or the model results such as those from DeConto and Pollard (2016) or Sutter et al. (2016). These authors used a dynamic ice-sheet model, forced with climate model output and calibrated to reproduce LIG sea-level estimates, to simulate the Antarctic ice sheet at $128 \mathrm{ka}$. All other boundary conditions should be implemented as in the baseline lig127k simulation. An additional sensitivity simulation (lig127k-gris) to complement the lig127k simulations is proposed in which the Greenland ice sheet is configured to its minimum LIG extent is also of interest, using configurations obtained from offline simulations, for example from ISMIP6.

\subsection{Freshwater forcing}

Sensitivity to the H11 meltwater event during the early $L I G$. Heinrich layers in the North Atlantic, containing high concentrations of IRD, record multiple examples of prolonged iceberg discharge during the past $500 \mathrm{ka}$ (Hemming, 2004; Marino et al., 2015; McManus et al., 1999). Heinrich event 11 (H11) is a well-documented example that occurred from $\sim 135$ to $128 \mathrm{ka}$ (Marino et al., 2015). The associated freshwater flux has been estimated as peaking at $\sim 0.3 \mathrm{~Sv}$ at $\sim 132.5 \mathrm{ka}$ and tapering off thereafter (Marino et al., 2015 ), and is broadly consistent with an estimate of $0.19 \mathrm{~Sv}$ at $130 \mathrm{ka}$ based on coral records (Carlson, 2008). There is also evidence of a rapid sea-level rise associated with this meltwater pulse, estimated at $\sim 70 \mathrm{~m}$ or $28 \pm 8 \mathrm{~m} \mathrm{ka}^{-1}$ $(\sim 0.32 \pm 0.09 \mathrm{~Sv})$ during the deglacial transition (Grant et al., 2012). Model simulations have shown that the freshwater forcing of H11, including its cessation, may be important for explaining the evolution of climate through the early part of the LIG (Goelzer et al., 2016a, b; Holden et al., 2010; Loutre et al., 2014; Stone et al., 2016). We propose a sensitivity experiment (lig 127k-H11) to examine the impact of the H11 event. The insolation anomalies at $130 \mathrm{ka}$ are similar to those at $127 \mathrm{ka}$. Therefore the experiment can be made by adding a persistent flux of $0.2 \mathrm{~Sv}$ to the North Atlantic between 50 and $70^{\circ} \mathrm{N}$ for 1000 years, with all other boundary conditions implemented as in the baseline lig127k simulation (Table 2).

Sensitivity to the $8.2 \mathrm{ka}$ freshwater event during the early Holocene. While the climate impact of the $8.2 \mathrm{ka}$ event is well documented, the magnitude of the freshwater forcing and its duration are less well constrained. There are generally thought to be two components to the freshwater forcing in the early Holocene, a background flux from the Laurentide ice sheet (Hillaire-Marcel et al., 2007; Licciardi et al., 1999) and catastrophic flux from the drainage of Lake Agassiz (Barber et al., 1999; Clarke et al., 2004; Teller et al., 2002). Lake
Agassiz appears to have drained in several flood events of relatively short duration, but with an estimated total discharge into the Labrador Sea of ca. $151400 \mathrm{~km}^{3}$ (Andrews et al., 1995, 1999; Clarke et al., 2004, 2009; Ellison et al., 2006; Hillaire-Marcel et al., 2007; Kerwin, 1996; Lajeunesse and St-Onge, 2008; Lewis et al., 2012; Roy et al., 2011). The background flux is smaller (ca. $0.13 \mathrm{~Sv}$ ) but persistent for several hundred years (Carlson et al., 2008b, 2009; Clarke et al., 2009; Hillaire-Marcel et al., 2007). The proposed sensitivity experiment (hol8.2k) can use the orbital, ice-sheet, and GHG boundary conditions of the $9.5 \mathrm{ka}$ experiment. The "Lake + Ice_100 years" scenario of Wagner et al. (2013) is more consistent with ice dynamics and the data of Carlson et al. (2009) than the shorter 1-year flood scenarios (Morrill et al., 2013) and should be adopted for this sensitivity experiment. That is, modeling groups should impose a single input of $2.5 \mathrm{~Sv}$ for 1 year followed by a background freshwater flux of $0.13 \mathrm{~Sv}$ for 99 years (Table 2). This freshwater flux is added to the Labrador Sea, but modeling groups can choose whether to add it uniformly over the whole of the Labrador Sea or only over part of the area.

These simulations should be run a minimum of 100 years after the end of the pulse and if possible even longer, preferably until the Atlantic Meridional Overturning Circulation (AMOC) has recovered to its initial state.

\subsection{Transient Holocene and LIG simulations}

Transient simulations provide an opportunity to examine the time-dependent evolution of climate in response to forcings and feedbacks. Transient simulations of the last deglaciation are a major focus in PMIP4 (Ivanovic et al., 2016). These simulations will be run for the period 21 to $9 \mathrm{ka}$ with time-varying orbital forcing, greenhouse gases, ice sheets and other geographical changes. The later part of this experiment is obviously of interest for comparison with the early Holocene experiments. However, we are also proposing transient simulations focusing on the Holocene and the LIG.

Using the PMIP-CMIP6 midHolocene simulation as a starting point, we propose a transient simulation of the last 6000 years (past6k). In this simulation, both orbital parameters and GHGs will be changed following Berger and Loutre (1991) and ice-core measurements (as described in Sect. 2.2). Changes in paleotopography over the past $6 \mathrm{ka}$ are small and, for simplicity and consistency with the midHolocene simulation, we propose using modern values throughout. Vegetation and aerosols will also be fixed at preindustrial values, except for groups running fully dynamic vegetation and/or aerosol models where the initial state of these components will be derived from their midHolocene simulation. Alternatively, some groups may start the Holocene transient simulation from the end of the last deglaciation experiment at $9 \mathrm{ka}$, incorporating changes in the evolution of ice sheets and paleotopography consistent with that experiment. A proposed LIG transient simulation 
(lig127to121k) will be run from 127 to $121 \mathrm{ka}$, using appropriate changes in orbital forcing and trace gases but with all other boundary conditions specified as in the lig127k simulation. These simulations as well as simulations planned by some modeling groups with climate-ice-sheet models will be important as input for addressing the role of coupling between climate and the ice sheets.

\section{Paleoenvironmental data and climate reconstructions for comparison to model simulations}

The ability to evaluate the realism of the Tier 1 PMIP4CMIP6 simulations and the various sensitivity experiments is central to PMIP. Some paleoenvironmental observations can be used for direct comparison with model outputs, including, e.g., simulated water balance against lake-level reconstructions (e.g., Coe and Harrison, 2002) or simulated vegetation patterns against pollen-based vegetation reconstructions (e.g., Perez Sanz et al., 2014). Such qualitative comparisons are often adequate to evaluate simulations when, as is the case with regional climate changes in the mid-Holocene and LIG, the changes are large and regionally coherent (Harrison and Bartlein, 2012). There are also quantitative reconstructions of climate variables from a wide variety of archives. There are uncertainties associated with such reconstructions, both statistical and resulting from an incomplete understanding of the climate controls on specific types of records, and these uncertainties need to be taken into account in comparisons with simulations. However, an increasing number of process-based models can be used to translate climate model outputs into explicit simulations of specific paleo-records (Emile-Geay and Tingley, 2016; Li et al., 2014; Thompson et al., 2011), allowing uncertainties in process understanding to be made explicit. Drawing on ongoing work for the LGM and the use of ocean biochemistry, tracer and isotopic modeling, efforts will be made to isolate key features of the ocean reconstructions that should be reproduced by climate models.

The major analytical focus for the Holocene experiments is on systematic benchmarking (Harrison et al., 2015) of the midHolocene simulation, analysis of feedbacks, and elucidation of the relationship between mean climate state and interannual to centennial variability. Analysis of the midHolocene simulation and associated sensitivity experiments benefits from the fact that there has been a major focus on data synthesis for this time period (Bartlein et al., 2011; Bigelow and al., 2003; Daniau et al., 2012; Emile-Geay et al., 2016; Hessler et al., 2014; Kohfeld and Harrison, 2000; Leduc et al., 2010; Marchant et al., 2009; Marlon et al., 2013; Pickett et al., 2004; Prentice et al., 2000). Thus the number of records and spatial coverage of quantitative reconstructions are relatively extensive (Bartlein et al., 2011; Hessler et al., 2014). There are gaps in coverage from continental regions, particularly in the $\mathrm{SH}$, but this situation is likely to improve in the near future (Flantua et al., 2015; Herbert and Harrison, 2016). Knowledge of ocean conditions during the mid-Holocene is poor and likely to remain so, in part because of incomplete understanding of the causes of differences between sea-surface temperature reconstructions based on different biological groups and in part because the signal-to-noise ratio in the reconstructions is small due to other methodological uncertainties (Hessler et al., 2014; Jonkers and Kucera, 2015; Rosell-Mele and Prahl, 2013). There are several sources of information about short-term climate variability during the Holocene, including tree-ring records, speleothems, corals and molluscs. However, there are major gaps in data coverage from the tropical oceans that challenge our understanding of ENSO variability; the distribution of speleothem records is limited to karst areas; and few tropical trees show clear-cut seasonality in growth. More comprehensive syntheses of these data are needed, and there are major challenges in combining the different data sources to yield large-scale reconstructions of climate variability. It will also be necessary to develop appropriate methods to use these data for comparison with simulations, focusing on temporal statistics and teleconnection patterns (Emile-Geay et al., 2016; Emile-Geay and Tingley, 2016).

There are many individual records documenting the evolution of climate through the Holocene, including quantitative climate reconstructions (Wanner et al., 2008). Synthetic products have either focused on reconstructions of global temperature changes (Clark et al., 2012; Marcott et al., 2013; Shakun et al., 2012), or are available as geographically explicit data sets only for a limited number of climate variables in a few regions such as North America or Europe (Davis et al., 2003; Gajewski, 2015; Mauri et al., 2014; Viau and Gajewski, 2009; Viau et al., 2006). The only exception to this is the Global Lake Status Data Base (Kohfeld and Harrison, 2000), which provides qualitative estimates of the change in lake water balance through time globally. The reliability of global temperature estimates depends on the representativeness of the data included; this point has been made abundantly clear from comparisons of records of hemispheric temperature changes during the last millennium (Fernández-Donado et al., 2013; Moberg, 2013). Currently available reconstructions of global temperature changes during the Holocene are heavily biased towards marine records, making it imperative that the reliability of these records is assessed using continental reconstructions (Davis et al., 2015; Liu et al., 2014). The lack of geographically explicit reconstructions for tropical regions and the SH would limit analysis of the Holocene transient simulations, but efforts are underway to improve this situation.

The LIG is the most suitable of the pre-Holocene interglacial periods as a focus in PMIP4-CMIP6 because of the relative wealth of data compared to earlier interglacial periods. However, there is an order of magnitude less information than for the Holocene, and there are larger uncertainties in dating of specific events. This means that the LIG data- 
model comparisons will focus on large-scale features, such as the strength of the high-latitude amplification of warming and the role of snow and sea-ice feedbacks in this warming. There will also be a major focus on the tropical water cycle. These analyses will exploit available data sets for the LIG which mostly document surface sea and air temperatures across the globe (Anderson et al., 2006; Brewer et al., 2008; Capron et al., 2014; Hoffman et al., 2017; McKay et al., 2011; Turney and Jones, 2010), although recent efforts also synthesize reconstructions of sea-ice changes (Esper and Gersonde, 2014; Sime et al., 2013), of the deep ocean circulation (Oliver et al., 2010), and to a lesser extent the tropical hydrological cycle (Govin et al., 2014). In addition, several existing maps are reporting vegetation changes at the $\mathrm{NH}$ high latitudes (Bennike et al., 2001) and changes in lake area in the Sahara (Petit-Maire, 1999).

There are also syntheses of quantitative climate reconstructions for the LIG (Turney and Jones, 2010; McKay et al., 2011; Capron et al., 2014; Hoffman et al., 2017), which have been used for model evaluation (e.g., Lunt et al., 2013; Otto-Bliesner et al., 2013). A critical evaluation of these LIG data syntheses is available in Capron et al. (2017), and we summarize here key aspects of the comparison. The major limitation in using the data syntheses by Turney and Jones (2010) and McKay et al. (2011) for analysis of the lig $127 \mathrm{k}$ simulations and associated sensitivity experiments is that they are compilations of information about the maximum warmth during the LIG. Given that warming was not synchronous globally (Bauch and Erlenkeuser, 2008; Cortese et al., 2007; NEEM Community Members, 2013; Govin et al., 2012; Masson-Delmotte et al., 2010; Mor et al., 2012; Winsor et al., 2012), these syntheses do not represent a specific time slice. A more recent compilation by Capron et al. (2014) has used harmonized chronologies for ice and marine records to produce records of the change in high-latitude temperature compared to present for four 2000-year long time slabs, and this approach has been expanded to include the fifth time slab (128-126 ka) for comparison with the lig $127 \mathrm{k}$ simulation (Capron et al., 2017). Following a similar strategy, Hoffman et al. (2017) propose the first global marine compilation with harmonized chronologies for the LIG, with time slabs available at 129 and $125 \mathrm{ka}$ but not $127 \mathrm{ka}$ (note that a high-latitude subset of the Hoffman et al. (2017) compilation at $127 \mathrm{ka}$ is available in Capron et al., 2017). However, even though these compilations are based on harmonized chronologies, dating uncertainties during the LIG can still be several thousand years depending on the type of archive and the dating methods (Govin et al., 2015). Furthermore, the different response scales of different components of the climate system mean that records from the 128-126 ka time slab may still bear the imprint of the previous deglaciation (Fig. 1) (Capron et al., 2017). In any case, and as with the early Holocene experiments, the lig $127 k$ simulation will not solely reflect the insolation forcing. It is therefore recommended that data-model comparisons focus on using the temporal evolution of climate, as captured in the available Capron et al. (2014) and the Hoffman et al. (2017) time series, to assess the plausibility of the lig127k simulation.

The public-access reconstruction data sets currently available for the mid-Holocene and LIG serve different functions and address different aspects of the climate system. Modeling groups running mid-Holocene and LIG simulations, or sensitivity experiments, are encouraged to use multiple reconstruction data sets for a full diagnosis of the simulations. Many of these data sets provide measures of the uncertainty of the reconstructions and data-model comparisons should be designed to take these uncertainties into account.

\section{Conclusions}

The PMIP4-CMIP6 midHolocene and lig127k simulations provide an opportunity to examine the impact of two different changes in radiative forcing on climate at times when other forcings were relatively similar to present. Together with planned sensitivity experiments, this focus on the two interglacials will allow us to explore the role of feedbacks in the climate system and to quantify their contribution to largescale phenomena relevant to future projections such as landsea contrast and high-latitude amplification of temperature changes. They will also allow us to address the implications of changes in forcing and feedbacks for the tropical circulation and monsoons - again an issue that is relevant to interpreting future projections. Given that both periods have been foci for model-model and data-model comparisons during previous phases of PMIP, a major focus during CMIP6 will be on evaluating the realism of the midHolocene and lig127k simulations using a wide range of paleoenvironmental data and paleoclimate reconstructions. This evaluation will be a direct out-of-sample test of the reliability of state-of-the-art models to simulate climate changes, and particularly the climate warming.

Neither one of these interglacial simulations is a perfect analog for the future, and each interglacial has distinct differences in forcings and in the initial state of the climate system. In a sense this is advantageous because it allows us to investigate the response of the system under different conditions. Sensitivity studies allow us to assess which results may be directly transferrable to future climate projections. In the case of the midHolocene simulations, we have the advantageous ability to assess Earth's response to elevated boreal summer insolation alone, with which we can compare model results against a plethora of observations. Estimated boreal summer warming for this period is roughly equivalent to the summer warming simulated for the mid to late 21 st century. In the case of the lig127k simulations, we have another advantageous end member where boreal summer insolation was even greater than the middle Holocene and that forced eventually higher-than-present sea levels. Higher temperatures in the polar regions, particularly during the summer months, 
directly influence sea ice and the ice sheets. The data evidence provides a means of evaluating whether we are capturing this sensitivity correctly in models being used for projections of future climate change. Consequently, this provides a potential imperfect analog for the end of this century and beyond. For example, Blaschek et al. (2015) found that the influence of freshwater forcing due to Greenland ice-sheet melting is the same, regardless of the background climate. In other cases, the response may be more strongly dependent upon the initial state, such as the response of polar amplification in Greenland, which was found to be sensitive to the prescribed ice-sheet elevation (Masson-Delmotte et al., 2006).

PMIP4 will collaborate with other CMIP6 projects (Kagayema et al., 2016). The output from the lig127k simulation, for example, will be used to force standalone ice-sheet experiments (ism-lig127k-std) in ISMIP6. This will complement the suite of standalone ISMIP6 ice-sheet experiments (Nowicki et al., 2016; http://www.climate-cryosphere.org/ activities/targeted/ismip6) for the recent past and future and will add to increase our understanding of the ice-sheet sensitivity to climate changes. The PMIP4-CMIP6 midHolocene and lig127k simulations, and associated sensitivity experiments, are also relevant to analyses of sea-ice feedbacks to climate in SIMIP (Notz et al., 2016) and to assessments of the role of dust forcing by AerChemMIP (Collins et al., 2017). Beyond CMIP6, the planned PMIP4-CMIP6 interglacial simulations are relevant to the Grand Challenges set by the World Climate Research Programme (WCRP). Both the midHolocene and the lig127k simulations are relevant to the Grand Challenge "Clouds, Circulation and Climate Sensitivity", which has a major focus on the controls on the monsoon circulation. Also, the lig127k simulation is particularly relevant to the Grand Challenge "Melting Ice and Global Consequences", which addresses the stability of the ice sheets. Those simulations carried out with biogeochemical cycles enabled are relevant to the Grand Challenge "Carbon Feedbacks in the Climate System".

Data availability. The forcing and boundary condition data sets described in this paper are available in the PMIP4 repository (2017) https://pmip4.lsce.ipsl.fr/doku.php/exp_design:index. After final acceptance of this paper, they will be made available also through Input4MIPs (https://esgf-node.llnl.gov/projects/ input4mips/; see the "Input4MIPs summary" living document there on the progress of this process).

The Tier 1 midHolocene and lig127k simulations are part of the CMIP6 experiment family and data will be distributed through the official CMIP6 channels via the Earth System Grid Federation (ESGF, https://earthsystemcog.org/projects/wip/ CMIP6DataRequest). A minimum of 100 years of output is required to be uploaded for each simulation (usually the final 100 years of the simulation). However, given the increasing interest in analyzing multi-decadal variability (e.g., Wittenberg, 2009) and the availability of reconstructions of ENSO (El Niño-Southern Oscillation) and other modes of variability (see Sect. 4), modeling groups are encouraged to provide outputs for at least 500 years if possible.

In addition, the difference in orbital configuration between $127 \mathrm{ka}, 6 \mathrm{ka}$ and preindustrial means that there are differences in month and season length that should be accounted for in calculating seasonal changes (Kutzbach and Gallimore, 1988). To be able to account for this effect when comparing the simulations to the paleoclimate reconstructions, daily outputs of at least surface $2 \mathrm{~m}$ temperature (tas), precipitation (pr) and $10 \mathrm{~m}$ winds (uas) should be archived. If not possible, a less accurate but probably adequate approach would be to use a program that provides an approximate estimate of monthly means on the fixed-angular celestial calendar from the fixed-day calendar.

Data from PMIP4-only Tier 2 and 3 simulations must be processed following the same standards as Tier 1 for data processing (e.g., CMOR standards) and should be distributed via the PMIP4 ESGF or the CMIP6 ESGF Tier 2 and Tier 3 databases. Modeling groups producing these simulations are responsible for securing suitable space on ESGF nodes. These experiments will follow the same naming, variable convention and format, and documentation requests as the Tier 1 PMIP4-CMIP6 experiment so as to be compliant with ESGF database requirements.

The list of variables requested for the PMIP4-CMIP6 paleoclimate experiments can be found here: http://clipc-services. ceda.ac.uk/dreq/u/PMIP.html. This request is presently processed by the CMIP6 Working Group for Coupled Modeling Infrastructure Panel (WIP) into tables, which define the variables included in the data request to the modeling groups for data to be contributed to the archive. The most up-to-date list including all variables requested for CMIP6 can be found at the WIP site: http://proj.badc.rl.ac.uk/svn/exarch/CMIP6dreq/tags/ latest/dreqPy/docs/CMIP6_MIP_tables.xlsx.

The last two columns in each row list MIPs associated with each variable. The first column in this pair lists the MIPs, which request the variable in one or more experiments. The second column lists the MIPs proposing experiments in which this variable is requested.

As the Supplement to this paper we provide version 1.00.05 (April 2017). We note, however, that this document is still in development and that inconsistencies may still exist.

The only variables defined specifically in PMIP are those describing oxygen isotopes for model systems that calculate these data interactively (Kageyama et al., 2016).

This list represents what is currently available from the official CMIP6 source (http://proj.badc.rl.ac.uk/svn/exarch/CMIP6dreq/ tags/latest/dreqPy/docs/CMIP6_MIP_tables.xlsx).

For updates, users should refer to the website with the PMIP data request (https://pmip4.lsce.ipsl.fr/doku.php/database: pmip4request\#the_pmip4_request).

\section{The Supplement related to this article is available online at https://doi.org/10.5194/gmd-10-3979-2017- supplement.}

Competing interests. The authors declare that they have no conflict of interest. 
Acknowledgements. Bette L. Otto-Bliesner acknowledges the funding by the U.S. National Science Foundation of the National Center for Atmospheric Research. Pascale Braconnot and Sandy P. Harrison acknowledge funding from JPI-Belmont project "PaleaoConstraints on Monsoon Evolution and Dynamics (PACMEDY)" through their national funding agencies. Sandy P. Harrison also acknowledges funding from the European Research Council for "GC2.0: Unlocking the past for a clearer future". Emilie Capron is funded by the European Union's Seventh Framework Programme for research and innovation under Marie Skłodowska-Curie grant agreement no. 600207.

Anders E. Carlson is funded by NSF grants PLR - 0902571, PLR - 1443437, and AGS - 1503032. Andrea Dutton is funded by NSF grant OCE 1559040 . Heiko Goelzer has received funding from the program of the Netherlands Earth System Science Centre (NESSC), financially supported by the Dutch Ministry of Education, Culture and Science (OCW) under grant number 024.002.001. Alan Haywood acknowledges that his contribution to this research was funded by the European Research Council under the European Union's Seventh Framework Programme (FP7/2007-2013)/ERC grant agreement number 278636. Fortunat Joos, Hubertus Fischer, and Christoph Nehrbass-Ahles acknowledge support by the Swiss National Science Foundation. William H. Lipscomb acknowledges support from the Regional and Global Climate Modeling program of the Office of Biological and Environmental Research within the U.S. Department of Energy's Office of Science.

Francesco S.-R. Pausata acknowledges funding from the Swedish Research Council (FORMAS) as part of the Joint Programming Initiative on Climate and the Belmont Forum for the project "Paleao-Constraints on Monsoon Evolution and Dynamics (PACMEDY)". Steven Phipps was supported by the Australian Research Council's Special Research Initiative for the Antarctic Gateway Partnership (project ID SR140300001). Qiong Zhang acknowledges funding from the Swedish Research Council VR for "Greenland in a warming Arctic".

This work is a contribution to the PAGES/PMIP QUIGS Working Group and PALSEA2 (INQUA IFG/PAGES WG). This is LSCE publication number 6047.

Edited by: Didier Roche

Reviewed by: Julie Brigham-Grette and two anonymous referees

\section{References}

Albani, S., Mahowald, N. M., Winckler, G., Anderson, R. F., Bradtmiller, L. I., Delmonte, B., François, R., Goman, M., Heavens, N. G., Hesse, P. P., Hovan, S. A., Kang, S. G., Kohfeld, K. E., Lu, H., Maggi, V., Mason, J. A., Mayewski, P. A., McGee, D., Miao, X., Otto-Bliesner, B. L., Perry, A. T., Pourmand, A., Roberts, H. M., Rosenbloom, N., Stevens, T., and Sun, J.: Twelve thousand years of dust: the Holocene global dust cycle constrained by natural archives, Clim. Past, 11, 869-903, https://doi.org/10.5194/cp-11869-2015, 2015.

Albani, S., Mahowald, N. M., Murphy, L. N., Raiswell, R., Moore, J. K., Anderson, R. F., McGee, D., Bradtmiller, L. I., Delmonte, B., Hesse, P. P., and Mayewski, P. A.: Paleodust variability since the Last Glacial Maximum and implications for iron inputs to the ocean, Geophys. Res. Lett., 43, 3944-3954, 2016.
Anderson, P., Bermike, O., Bigelow, N., Brigham-Grette, J., Duvall, M., Edwards, M., Frechette, B., Funder, S., Johnsen, S., Knies, J., Koerner, R., Lozhkin, A., Marshall, S., Matthiessen, J., Macdonald, G., Miller, G., Montoya, M., Muhs, D., Otto-Bliesner, B., Overpeck, J., Reeh, N., Sejrup, H. P., Spielhagen, R., Turner, C., Velichko, A., and Mem, C. A.-L. I. P.: Last Interglacial Arctic warmth confirms polar amplification of climate change, Quaternary Sci. Rev., 25, 1383-1400, 2006.

Andrews, J. T., Keigwin, L., Hall, F., and Jennings, A. E.: Abrupt deglaciation events and holocene palaeoceanography from highresolution cores, Cartwright Saddle, Labrador Shelf, Canada, J. Quaternary Sci., 14, 383-397, 1999.

Andrews, J. T., MacLean, B., Kerwin, M., Manley, W., Jennings, A. E., and Hall, F.: Final stages in the collapse of the Laurentide Ice Sheet, Hudson Strait, Canada, NWT: C-14 AMS dates, seismic stratigraphy, and magnetic susceptibility logs, Quaternary Sci Rev., 14, 983-1004, 1995.

Bakker, P., Stone, E. J., Charbit, S., Gröger, M., Krebs-Kanzow, U., Ritz, S. P., Varma, V., Khon, V., Lunt, D. J., Mikolajewicz, U., Prange, M., Renssen, H., Schneider, B., and Schulz, M.: Last interglacial temperature evolution - a model inter-comparison, Clim. Past, 9, 605-619, https://doi.org/10.5194/cp-9-605-2013, 2013.

Barber, D. C., Dyke, A., Hillaire-Marcel, C., Jennings, A. E., Andrews, J. T., Kerwin, M. W., Bilodeau, G., McNeely, R., Southon, J., Morehead, M. D., and Gagnon, J. M.: Forcing of the cold event of 8,200 years ago by catastrophic drainage of Laurentide lakes, Nature, 400, 344-348, 1999.

Bartlein, P. J., Harrison, S. P., Brewer, S., Connor, S., Davis, B. A S., Gajewski, K., Guiot, J., Harrison-Prentice, T. I., Henderson, A., Peyron, O., Prentice, I. C., Scholze, M., Seppa, H., Shuman, B., Sugita, S., Thompson, R. S., Viau, A. E., Williams, J., and Wu, H.: Pollen-based continental climate reconstructions at 6 and 21 ka: a global synthesis, Clim. Dynam., 37, 775-802, 2011.

Bauch, H. A.: Interglacial climates and the Atlantic meridional overturning circulation: is there an Arctic controversy?, Quaternary Sci. Rev., 63, 1-22, 2013.

Bauch, H. A. and Erlenkeuser, H.: A "critical" climatic evaluation of last interglacial (MIS 5e) records from the Norwegian Sea, Polar Res., 27, 135-151, 2008.

Bazin, L., Landais, A., Lemieux-Dudon, B., Toyé Mahamadou Kele, H., Veres, D., Parrenin, F., Martinerie, P., Ritz, C., Capron, E., Lipenkov, V., Loutre, M.-F., Raynaud, D., Vinther, B., Svensson, A., Rasmussen, S. O., Severi, M., Blunier, T., Leuenberger, M., Fischer, H., Masson-Delmotte, V., Chappellaz, J., and Wolff, E.: An optimized multi-proxy, multi-site Antarctic ice and gas orbital chronology (AICC2012): 120-800 ka, Clim. Past, 9, 17151731, https://doi.org/10.5194/cp-9-1715-2013, 2013.

Bennike, O., Bolshiyanov, D., Dowdeswell, J., Elverhoi, A., Geirsdottir, A., Hicks, S., Hubberton, H., Ingolfsson, O., Miller, G., and Members, C. P.: Holocene paleoclimate data from the Arctic: testing models of global climate change, Quaternary Sci. Rev., 20, 1275-1287, 2001.

Bereiter, B., Eggleston, S., Schmitt, J., Nehrbass-Ahles, C., Stocker, T. F., Fischer, H., Kipfstuhl, S., and Chappellaz, J.: Revision of the EPICA Dome $\mathrm{C} \mathrm{CO}_{2}$ record from 800 to $600 \mathrm{kyr}$ before present, Geophys. Res. Lett., 42, 542-549, 2015. 
Berger, A. L.: Long-term variations of caloric insolation resulting from the earth's orbital elements, Quaternary Res., 9, 139-167, 1978.

Berger, A. and Loutre, M. F.: insolation values for the climate of the last 10000000 years, Quaternary Sci. Rev., 10, 297-317, https://doi.org/10.1016/0277-3791(91)90033-q, 1991.

Bigelow, N. H., Brubaker, L. B., Edwards, M. E., Harrison, S. P., Prentice, I. C., Anderson, P. M., Andreev, A. A., Bartlein, P. J., Christensen, T. R., Cramer, W., Kaplan, J. O., Lozhkin, A. V., Matveyeva, N. V., Murray, D. F., McGuire, A. D., Razzhivin, V. Y., Ritchie, J. C., Smith, B., Walker, D. A., Gajewski, K., Wolf, V., Holmqvist, B. H., Igarashi, Y., Kremenetskii, K., Paus, A., Pisaric, M. F. J., and Volkova, V. S.: Climate change and Arctic ecosystems: 1 . Vegetation changes north of $55^{\circ} \mathrm{N}$ between the last glacial maximum, mid-Holocene, and present, J. Geophys. Res., 108, 8170, https://doi.org/10.1029/2002JD002558, 2003.

Binney, H., Edwards, M., Macias-Fauria, M., Lozhkin, A., Anderson, P., Kaplan, J. O., Andreev, A., Bezrukova, E., Blyakharchuk, T., Jankovska, V., Khazina, I., Krivonogov, S., Kremenetski, K., Nield, J., Novenko, E., Ryabogina, N., Solovieva, N., Willis, K., and Zernitskaya, V.: Vegetation of Eurasia from the last glacial maximum to present: Key biogeographic patterns, Quaternary Sci. Rev., 157, 80-97, 2017.

Blaschek, M., Bakker, P., and Renssen, H.: The influence of Greenland ice sheet melting on the Atlantic meridional overturning circulation during past and future warm periods: a model study, Clim. Dynam., 44, 2137-2157, 2015.

Blunier, T., Chappellaz, J., Schwander, J., Stauffer, B., and Raynaud, D.: Variations in atmospheric methane concentration during the Holocene epoch, Nature, 374, 46-49, 1995.

Braconnot, P., Joussaume, S., Marti, O., and de Noblet, N.: Synergistic feedbacks from ocean and vegetation on the African monsoon response to mid-Holocene insolation, Geophys. Res. Lett., 26, 2481-2484, 1999.

Braconnot, P., Otto-Bliesner, B., Harrison, S., Joussaume, S., Peterchmitt, J.-Y., Abe-Ouchi, A., Crucifix, M., Driesschaert, E., Fichefet, Th., Hewitt, C. D., Kageyama, M., Kitoh, A., Loutre, M.-F., Marti, O., Merkel, U., Ramstein, G., Valdes, P., Weber, L., Yu, Y., and Zhao, Y.: Results of PMIP2 coupled simulations of the Mid-Holocene and Last Glacial Maximum - Part 2: feedbacks with emphasis on the location of the ITCZ and mid- and high latitudes heat budget, Clim. Past, 3, 279-296, https://doi.org/10.5194/cp-3-279-2007, 2007a.

Braconnot, P., Otto-Bliesner, B., Harrison, S., Joussaume, S., Peterchmitt, J.-Y., Abe-Ouchi, A., Crucifix, M., Driesschaert, E., Fichefet, Th., Hewitt, C. D., Kageyama, M., Kitoh, A., Laîné, A., Loutre, M.-F., Marti, O., Merkel, U., Ramstein, G., Valdes, P., Weber, S. L., Yu, Y., and Zhao, Y.: Results of PMIP2 coupled simulations of the Mid-Holocene and Last Glacial Maximum Part 1: experiments and large-scale features, Clim. Past, 3, 261277, https://doi.org/10.5194/cp-3-261-2007, 2007 b.

Braconnot, P., Marzin, C., Grégoire, L., Mosquet, E., and Marti, O.: Monsoon response to changes in Earth's orbital parameters: comparisons between simulations of the Eemian and of the Holocene, Clim. Past, 4, 281-294, https://doi.org/10.5194/cp-4-281-2008, 2008.

Braconnot, P., Harrison, S. P., Kageyama, M., Bartlein, P. J., Masson-Delmotte, V., Abe-Ouchi, A., Otto-Bliesner, B., and
Zhao, Y.: Evaluation of climate models using palaeoclimatic data, Nature Climate Change, 2, 417-424, 2012.

Brewer, S., Guiot, J., Sanchez-Goni, M. F., and Klotz, S.: The climate in Europe during the Eemian: a multi-method approach using pollen data, Quaternary Sci. Rev., 27, 2303-2315, 2008.

Brook, E. J.: Methane Measurements from the GISP2 and Siple Dome Ice Cores, National Snow and Ice Data Center, Boulder, CO, USA, 2009.

Bruno, M. and Joos, F.: Terrestrial carbon storage during the past 200 years: A Monte Carlo analysis of $\mathrm{CO}_{2}$ data from ice core and atmospheric measurements, Global Biogeochem. Cy., 11, 111124, 1997.

Buiron, D., Chappellaz, J., Stenni, B., Frezzotti, M., Baumgartner, M., Capron, E., Landais, A., Lemieux-Dudon, B., MassonDelmotte, V., Montagnat, M., Parrenin, F., and Schilt, A.: TALDICE-1 age scale of the Talos Dome deep ice core, East Antarctica, Clim. Past, 7, 1-16, https://doi.org/10.5194/cp-7-12011, 2011.

Capron, E., Govin, A., Stone, E. J., Masson-Delmotte, V., Mulitza, S., Otto-Bliesner, B., Rasmussen, T. L., Sime, L. C., Waelbroeck, C., and Wolff, E. W.: Temporal and spatial structure of multimillennial temperature changes at high latitudes during the Last Interglacial, Quaternary Sci. Rev., 103, 116-133, 2014.

Capron, E., Govin, A., Feng, R., Otto-Bliesner, B., and Wolff, E. W.: Critical evaluation of climate syntheses to benchmark CMIP6/PMIP4 $127 \mathrm{ka}$ Last Interglacial simulations in the highlatitude regions, Quaternary Sci. Rev., 168, 137-150, 2017.

Carlson, A. E.: Why there was not a Younger Dryas-like event during the Penultimate Deglaciation, Quaternary Sci. Rev., 27, 882887, 2008.

Carlson, A. E. and Winsor, K.: Northern Hemisphere ice-sheet responses to past climate warming, Nat. Geosci., 5, 607-613, 2012.

Carlson, A. E., Stoner, J. S., Donnelly, J. P., and Hillaire-Marcel, C.: Response of the southern Greenland Ice Sheet during the last two deglaciations, Geology, 36, 359-362, 2008a.

Carlson, A. E., Legrande, A. N., Oppo, D. W., Came, R. E., Schmidt, G. A., Anslow, F. S., Licciardi, J. M., and Obbink, E. A.: Rapid early Holocene deglaciation of the Laurentide ice sheet, Nat. Geosci., 1, 620-624, 2008b.

Carlson, A. E., Clark, P. U., Haley, B. A., and Klinkhammer, G. P.: Routing of western Canadian Plains runoff during the $8.2 \mathrm{ka}$ cold event, Geophys. Res. Lett., 36, L14704, https://doi.org/10.1029/2009GL038778, 2009.

Carlson, A. E., Winsor, K., Ullman, D. J., Brook, E. J., Rood, D. H., Axford, Y., LeGrande, A. N., Anslow, F. S., and Sinclair, G.: Earliest Holocene south Greenland ice sheet retreat within its late Holocene extent, Geophys. Res. Lett., 41, 5514-5521, 2014.

Carre, M., Sachs, J. P., Purca, S., Schauer, A. J., Braconnot, P., Falcon, R. A., Julien, M., and Lavallee, D.: Holocene history of ENSO variance and asymmetry in the eastern tropical Pacific, Science, 345, 1045-1048, 2014.

Castaneda, I. S., Mulitza, S., Schefuss, E., dos Santos, R. A. L., Damste, J. S. S., and Schouten, S.: Wet phases in the Sahara/Sahel region and human migration patterns in North Africa, P. Natl. Acad. Sci. USA, 106, 20159-20163, 2009.

Chappellaz, J., Blunier, T., Kints, S., Dallenbach, A., Barnola, J. M., Schwander, J., Raynaud, D., and Stauffer, B.: Changes in the atmospheric $\mathrm{CH}_{4}$ gradient between Greenland and Antarctica dur- 
ing the Holocene, J. Geophys. Res.-Atmos., 102, 15987-15997, 1997.

Clark, C. D., Knight, J. K., and Gray, J. T.: Geomorphological reconstruction of the Labrador Sector of the Laurentide Ice Sheet, Quaternary Sci. Rev., 19, 1343-1366, 2000.

Clark, P. U., Shakun, J. D., Baker, P. A., Bartlein, P. J., Brewer, S., Brook, E., Carlson, A. E., Cheng, H., Kaufman, D. S., Liu, Z. Y., Marchitto, T. M., Mix, A. C., Morrill, C., Otto-Bliesner, B. L., Pahnke, K., Russell, J. M., Whitlock, C., Adkins, J. F., Blois, J. L., Clark, J., Colman, S. M., Curry, W. B., Flower, B. P., He, F., Johnson, T. C., Lynch-Stieglitz, J., Markgraf, V., McManus, J., Mitrovica, J. X., Moreno, P. I., and Williams, J. W.: Global climate evolution during the last deglaciation, P. Natl. Acad. Sci. USA, 109, E1134-E1142, 2012.

Clarke, G. K. C., Leverington, D. W., Teller, J. T., and Dyke, A. S.: Paleohydraulics of the last outburst flood from glacial Lake Agassiz and the 8200 BP cold event, Quaternary Sci. Rev., 23, 389-407, 2004.

Clarke, G. K. C., Bush, A. B. G., and Bush, J. W. M.: Freshwater Discharge, Sediment Transport, and Modeled Climate Impacts of the Final Drainage of Glacial Lake Agassiz, J. Climate, 22, 2161-2180, 2009.

Claussen, M. and Gayler, V.: The greening of the Sahara during the mid-Holocene: results of an interactive atmosphere-biome model, Global Ecol. Biogeogr., 6, 369-377, 1997.

Coe, M. T. and Harrison, S. P.: The water balance of northern Africa during the mid-Holocene: an evaluation of the $6 \mathrm{ka}$ BP PMIP experiments, Clim. Dynam., 19, 155-166, 2002.

COHMAP Members: Climatic changes of the last 18,000 years: observations and model simulations, Science, 241, 1043-1052, 1988.

Collins, W. J., Lamarque, J.-F., Schulz, M., Boucher, O., Eyring, V., Hegglin, M. I., Maycock, A., Myhre, G., Prather, M., Shindell, D., and Smith, S. J.: AerChemMIP: quantifying the effects of chemistry and aerosols in CMIP6, Geosci. Model Dev., 10, 585607, https://doi.org/10.5194/gmd-10-585-2017, 2017.

Colville, E. J., Carlson, A. E., Beard, B. L., Hatfield, R. G., Stoner, J. S., Reyes, A. V., and Ullman, D. J.: Sr-Nd-Pb Isotope Evidence for Ice-Sheet Presence on Southern Greenland During the Last Interglacial, Science, 333, 620-623, 2011.

Cortese, G., Abelmann, A., and Gersonde, R.: The last five glacialinterglacial transitions: A high-resolution 450,000-year record from the subantarctic Atlantic, Paleoceanography, 22, PA4203, https://doi.org/10.1029/2007pa001457, 2007.

Dallmeyer, A., Claussen, M., and Otto, J.: Contribution of oceanic and vegetation feedbacks to Holocene climate change in monsoonal Asia, Clim. Past, 6, 195-218, https://doi.org/10.5194/cp6-195-2010, 2010.

Daniau, A. L., Bartlein, P. J., Harrison, S. P., Prentice, I. C., Brewer, S., Friedlingstein, P., Harrison-Prentice, T. I., Inoue, J., Izumi, K., Marlon, J. R., Mooney, S., Power, M. J., Stevenson, J., Tinner, W., Andric, M., Atanassova, J., Behling, H., Black, M., Blarquez, O., Brown, K. J., Carcaillet, C., Colhoun, E. A., Colombaroli, D., Davis, B. A. S., D'Costa, D., Dodson, J., Dupont, L., Eshetu, Z., Gavin, D. G., Genries, A., Haberle, S., Hallett, D. J., Hope, G., Horn, S. P., Kassa, T. G., Katamura, F., Kennedy, L. M., Kershaw, P., Krivonogov, S., Long, C., Magri, D., Marinova, E., McKenzie, G. M., Moreno, P. I., Moss, P., Neumann, F. H., Norstrom, E., Paitre, C., Rius, D., Roberts, N., Robin- son, G. S., Sasaki, N., Scott, L., Takahara, H., Terwilliger, V., Thevenon, F., Turner, R., Valsecchi, V. G., Vanniere, B., Walsh, M., Williams, N., and Zhang, Y.: Predictability of biomass burning in response to climate changes, Global Biogeochem. Cy., 26, GB4007, https://doi.org/10.1029/2011GB004249, 2012.

Davis, B. A. S., Brewer, S., Stevenson, A. C., Guiot, J., and Data, C.: The temperature of Europe during the Holocene reconstructed from pollen data, Quaternary Sci. Rev., 22, 1701-1716, 2003.

Davis, B. A. S., Collins, P. M., and Kaplan, J. O.: The age and post-glacial development of the modern European vegetation: a plant functional approach based on pollen data, Veg. Hist. Archaeobot., 24, 303-317, 2015.

DeConto, R. M. and Pollard, D.: Contribution of Antarctica to past and future sea-level rise, Nature, 531, 591-597, 2016.

deMenocal, P., Ortiz, J., Guilderson, T., Adkins, J., Sarnthein, M., Baker, L., and Yarusinsky, M.: Abrupt onset and termination of the African Humid Period: rapid climate responses to gradual insolation forcing, Quaternary Sci. Rev., 19, 347-361, 2000.

Drake, N. A., Blench, R. M., Armitage, S. J., Bristow, C. S., and White, K. H.: Ancient watercourses and biogeography of the Sahara explain the peopling of the desert, P. Natl. Acad. Sci. USA, 108, 458-462, 2011.

Dufresne, J.-L., Foujols, M.-A., Denvil, S., Caubel, A., Marti, O., Aumont, O., Balkanski, Y., Bekki, S., Bellenger, H., Benshila, R., Bony, S., Bopp, L., Braconnot, P., Brockmann, P., Cadule, P., Cheruy, F., Codron, F., Cozic, A., Cugnet, D., de Noblet, N., Duvel, J.-P., Ethe, C., Fairhead, L., Fichefet, T., Flavoni, S., Friedlingstein, P., Grandpeix, J.-Y., Guez, L., Guilyardi, E., Hauglustaine, D., Hourdin, F., Idelkadi, A., Ghattas, J., Joussaume, S., Kageyama, M., Krinner, G., Labetoulle, S., Lahellec, A., Lefebvre, M.-P., Lefevre, F., Levy, C., Li, Z. X., Lloyd, J., Lott, F., Madec, G., Mancip, M., Marchand, M., Masson, S., Meurdesoif, Y., Mignot, J., Musat, I., Parouty, S., Polcher, J., Rio, C., Schulz, M., Swingedouw, D., Szopa, S., Talandier, C., Terray, P., Viovy, N., and Vuichard, N.: Climate change projections using the IPSL-CM5 Earth System Model: from CMIP3 to CMIP5, Clim. Dynam., 40, 2123-2165, 2013.

Dutton, A., Carlson, A. E., Long, A. J., Milne, G. A., Clark, P. U., DeConto, R., Horton, B. P., Rahmstorf, S., and Raymo, M. E.: Sea-level rise due to polar ice-sheet mass loss during past warm periods, Science, 349, https://doi.org/10.1126/science.aaa4019, 2015 a.

Dutton, A., Webster, J. M., Zwartz, D., Lambeck, K., and Wohlfarth, B.: Tropical tales of polar ice: evidence of Last Interglacial polar ice sheet retreat recorded by fossil reefs of the granitic Seychelles islands, Quaternary Sci. Rev., 107, 182-196, 2015 b.

Edwards, M. E., Hamilton, T. D., Elias, S. A., Bigelow, N. H., and Krumhardt, A. P.: Interglacial extension of the boreal forest limit in the Noatak Valley, northwest Alaska: Evidence from an exhumed river-cut bluff and debris apron, Arct. Antarct. Alp. Res., 35, 460-468, 2003.

Ellison, C. R. W., Chapman, M. R., and Hall, I. R.: Surface and deep ocean interactions during the cold climate event 8200 years ago, Science, 312, 1929-1932, 2006.

Emile-Geay, J. and Tingley, M.: Inferring climate variability from nonlinear proxies: application to palaeo-ENSO studies, Clim. Past, 12, 31-50, https://doi.org/10.5194/cp-12-31-2016, 2016.

Emile-Geay, J., Cobb, K. M., Carre, M., Braconnot, P., Leloup, J., Zhou, Y., Harrison, S. P., Correge, T., McGregor, H. V., Collins, 
M., Driscoll, R., Elliot, M., Schneider, B., and Tudhope, A.: Links between tropical Pacific seasonal, interannual and orbital variability during the Holocene, Nat. Geosci., 9, 168-173, 2016.

Engelstaedter, S., Kohfeld, K. E., Tegen, I., and Harrison, S. P.: Controls of dust emissions by vegetation and topographic depressions: An evaluation using dust storm frequency data Geophys. Res. Lett., 30, 1294, https://doi.org/10.1029/2002GL016471, 2003.

Enting, I. G.: On the use of smoothing splines to filter $\mathrm{CO}_{2}$ data, J. Geophys. Res.-Atmos., 92, 10977-10984, 1987.

EPICA Community Members: One-to-one coupling of glacial climate variability in Greenland and Antarctica, Nature, 444, 195198, 2006

Esper, O. and Gersonde, R.: New tools for the reconstruction of Pleistocene Antarctic sea ice, Palaeogeogr. Palaeocl., 399, 260283, 2014

Eyring, V., Bony, S., Meehl, G. A., Senior, C. A., Stevens, B., Stouffer, R. J., and Taylor, K. E.: Overview of the Coupled Model Intercomparison Project Phase 6 (CMIP6) experimental design and organization, Geosci. Model Dev., 9, 1937-1958, https://doi.org/10.5194/gmd-9-1937-2016, 2016.

Fernández-Donado, L., González-Rouco, J. F., Raible, C. C., Ammann, C. M., Barriopedro, D., García-Bustamante, E., Jungclaus, J. H., Lorenz, S. J., Luterbacher, J., Phipps, S. J., Servonnat, J., Swingedouw, D., Tett, S. F. B., Wagner, S., Yiou, P., and Zorita, E.: Large-scale temperature response to external forcing in simulations and reconstructions of the last millennium, Clim. Past, 9, 393-421, https://doi.org/10.5194/cp-9-393-2013, 2013.

Flantua, S. G. A., Hooghiemstra, H., Grimm, E. C., Behling, H., Bush, M. B., Gonzalez-Arango, C., Gosling, W. D., Ledru, M. P., Lozano-Garcia, S., Maldonado, A., Prieto, A. R., Rull, V., and Van Boxel, J. H.: Updated site compilation of the Latin American Pollen Database, Rev. Palaeobot. Palyno., 223, 104-115, 2015.

Flato, G., Marotzke, J., Abiodun, B., Braconnot, P., Chou, S. C., Collins, W., Cox, P., Driouech, F., Emori, S., Eyring, V., Forest, C., Gleckler, P., Guilyardi, E., Jakob, C., Kattsov, V., Reason, C., and Rummukainen, M.: Evaluation of Climate Models, in: Climate Change 2013: The Physical Science Basis. Contribution of Working Group I to the Fifth Assessment Report of the Intergovernmental Panel on Climate Change, edited by: Stocker, T. F., Qin, D., Plattner, G.-K., Tignor, M., Allen, S. K., Boschung, J., Nauels, A., Xia, Y., Bex, V., and Midgley, P. M., Cambridge University Press, Cambridge, United Kingdom and New York, NY, USA, 2013.

Flückiger, J., Monnin, E., Stauffer, B., Schwander, J., Stocker, T. F., Chappellaz, J., Raynaud, D., and Barnola, J. M.: High-resolution Holocene $\mathrm{N}_{2} \mathrm{O}$ ice core record and its relationship with $\mathrm{CH}_{4}$ and $\mathrm{CO}_{2}$, Global Biogeochem. Cy., 16, https://doi.org/10.1029/2001gb001417, 2002.

Folland, C. K., Karl, T. R., and Vinnikov, K. Y.: Observed climate variations and change, in: Climate Change: The IPCC Scientific Assessment, edited by: Houghton, J. T., Jenkins, G. J., and Ephraums, J., 195-238, Cambridge Univ. Press, New York, 1990.

Folland, C. I., Karl, T. R., Christy, J. R., Clarke, R. A., Gruza, G. V., Jouzel, J., Mann, M. E., Oerlemans, J., Salinger, M. J., and Wang, S.-W.: Observed climate variability and change, in: Climate Change 2001: The scientific basis. Contribution of Working Group I to the Third Assessment Report of the Intergovernmental Panel on Climate Change, edited by: Houghton, J. T., Ding, Y.,
Griggs, D. J., Noguer, M., van der Linden, P. J., Dai, X., Maskell, K., and Johnson, C. A., Cambridge University Press, Cambridge, United Kingdom and New York, NY, 2001.

Gajewski, K.: Impact of Holocene climate variability on Arctic vegetation, Global Planet. Change, 133, 272-287, 2015.

Goelzer, H., Huybrechts, P., Loutre, M.-F., and Fichefet, T.: Impact of ice sheet meltwater fluxes on the climate evolution at the onset of the Last Interglacial, Clim. Past, 12, 1721-1737, https://doi.org/10.5194/cp-12-1721-2016, 2016a.

Goelzer, H., Huybrechts, P., Loutre, M.-F., and Fichefet, T.: Last Interglacial climate and sea-level evolution from a coupled ice sheet-climate model, Clim. Past, 12, 2195-2213, https://doi.org/10.5194/cp-12-2195-2016, 2016 b.

Goni, M. F. S., Loutre, M. F., Crucifx, M., Peyron, O., Santos, L., Duprat, J., Malaize, B., Turon, J. L., and Peypouquet, J. P.: Increasing vegetation and climate gradient in Western Europe over the Last Glacial Inception (122-110 ka): data-model comparison, Earth Planet. Sc. Lett., 231, 111-130, 2005.

Govin, A., Braconnot, P., Capron, E., Cortijo, E., Duplessy, J.-C., Jansen, E., Labeyrie, L., Landais, A., Marti, O., Michel, E., Mosquet, E., Risebrobakken, B., Swingedouw, D., and Waelbroeck, C.: Persistent influence of ice sheet melting on high northern latitude climate during the early Last Interglacial, Clim. Past, 8, 483-507, https://doi.org/10.5194/cp-8-483-2012, 2012.

Govin, A., Varma, V., and Prange, M.: Astronomically forced variations in western African rainfall $\left(21^{\circ} \mathrm{N}-20^{\circ} \mathrm{S}\right)$ during the Last Interglacial period, Geophys. Res. Lett., 41, 2117-2125, 2014.

Govin, A., Capron, E., Tzedakis, P. C., Verheyden, S., Ghaleb, B., Hillaire-Marcel, C., St-Onge, G., Stoner, J. S., Bassinot, F., Bazin, L., Blunier, T., Combourieu-Nebout, N., El Ouahabi, A., Genty, D., Gersonde, R., Jimenez-Amat, P., Landais, A., Martrat, B., Masson-Delmotte, V., Parrenin, F., Seidenkrantz, M.-S., Veres, D., Waelbroeck, C., and Zahn, R.: Sequence of events from the onset to the demise of the Last Interglacial: Evaluating strengths and limitations of chronologies used in climatic archives, Quaternary Sci. Rev., 129, 1-36, https://doi.org/10.1016/j.quascirev.2015.09.018, 2015.

Grant, K. M., Rohling, E. J., Bar-Matthews, M., Ayalon, A., Medina-Elizalde, M., Ramsey, C. B., Satow, C., and Roberts, A. P.: Rapid coupling between ice volume and polar temperature over the past 150,000 years, Nature, 491, 744-747, 2012.

Harrison, S. P. and Bartlein, P. J.: Records from the past, lessons for the future: what the palaeo-record implies about mechanisms of global change, in: The Future of the World's Climates, edited by: Henderson-Sellers, A. and McGuffie, K., 403-436, 2012.

Harrison, S. P., Jolly, D., Laarif, F., Abe-Ouchi, A., Dong, B., Herterich, K., Hewitt, C., Joussaume, S., Kutzbach, J. E., Mitchell, J., De Noblet, N., and Valdes, P.: Intercomparison of simulated global vegetation distributions in response to $6 \mathrm{kyr}$ BP orbital forcing, J. Climate, 11, 2721-2742, 1998.

Harrison, S. P., Bartlein, P. J., Brewer, S., Prentice, I. C., Boyd, M., Hessler, I., Holmgren, K., Izumi, K., and Willis, K.: Climate model benchmarking with glacial and mid-Holocene climates, Clim. Dynam., 43, 671-688, 2014.

Harrison, S. P., Bartlein, P. J., Izumi, K., Li, G., Annan, J., Hargreaves, J., Braconnot, P., and Kageyama, M.: Evaluation of CMIP5 palaeo-simulations to improve climate projections, Nature Climate Change, 5, 735-743, 2015. 
Haywood, A. M., Dowsett, H. J., Dolan, A. M., Rowley, D., Abe-Ouchi, A., Otto-Bliesner, B., Chandler, M. A., Hunter, S. J., Lunt, D. J., Pound, M., and Salzmann, U.: The Pliocene Model Intercomparison Project (PlioMIP) Phase 2: scientific objectives and experimental design, Clim. Past, 12, 663-675, https://doi.org/10.5194/cp-12-663-2016, 2016.

Hegerl, G. C., Zwiers, F. W., Braconnot, P., Gillett, N. P., Luo, Y., Marengo Orsini, J. A., Nicholls, N., Penner, J. E., and Stott, P. A.: Understanding and Attributing Climate Change, in: Climate Change 2007: The Physical Science Basis. Contribution of Working Group I to the Fourth Assessment Report of the Intergovernmental Panel on Climate Change, edited by: Solomon, S., Qin, D., Manning, M., Chen, Z., Marquis, M., Averyt, K. B., Tignor, M., and Miller, H. L., Cambridge University Press, Cambridge, United Kingdom and New York, NY, USA, 2007.

Hély, C., Lézine, A.-M., and contributors, A.: Holocene changes in African vegetation: tradeoff between climate and water availability, Clim. Past, 10, 681-686, https://doi.org/10.5194/cp-10-6812014, 2014.

Hemming, S. R.: Heinrich events: Massive late pleistocene detritus layers of the North Atlantic and their global climate imprint, Rev. Geophys., 42, RG1005, https://doi.org/10.1029/2003RG000128, 2004.

Herbert, A. V. and Harrison, S. P.: Evaluation of a modern-analogue methodology for reconstructing Australian palaeoclimate from pollen, Rev. Palaeobot. Palyno., 226, 65-77, 2016.

Herrington, A. R. and Poulsen, C. J.: Terminating the Last Interglacial: The Role of Ice Sheet-Climate Feedbacks in a GCM Asynchronously Coupled to an Ice Sheet Model, J. Climate, 25, 1871-1882, 2012.

Hessler, I., Harrison, S. P., Kucera, M., Waelbroeck, C., Chen, M.T., Anderson, C., de Vernal, A., Fréchette, B., Cloke-Hayes, A., Leduc, G., and Londeix, L.: Implication of methodological uncertainties for mid-Holocene sea surface temperature reconstructions, Clim. Past, 10, 2237-2252, https://doi.org/10.5194/cp-102237-2014, 2014.

Hillaire-Marcel, C., de Vernal, A., and Piper, D. J. W.: Lake Agassiz final drainage event in the northwest North Atlantic, Geophys. Res. Lett., 34, L15601, https://doi.org/10.1029/2007GL030396, 2007.

Hoffman, J. S., Clark, P. U., Parnell, A. C., and He, F.: Regional and global sea-surface temperatures during the last interglaciation, Science, 355, 276-279, 2017.

Holden, P. B., Edwards, N. R., Wolff, E. W., Lang, N. J., Singarayer, J. S., Valdes, P. J., and Stocker, T. F.: Interhemispheric coupling, the West Antarctic Ice Sheet and warm Antarctic interglacials, Clim. Past, 6, 431-443, https://doi.org/10.5194/cp-6-431-2010, 2010

Hooghiemstra, H., Stalling, H., Agwu, C. O. C., and Dupont, L. M.: Vegetational and climatic changes at the northern fringe of the sahara 250,000-5000 years bp - evidence from 4 marine pollen records located between Portugal and the Canary-Islands, Rev. Palaeobot. Palyno., 74, 1-53, 1992.

Ivanovic, R. F., Gregoire, L. J., Kageyama, M., Roche, D. M., Valdes, P. J., Burke, A., Drummond, R., Peltier, W. R., and Tarasov, L.: Transient climate simulations of the deglaciation 219 thousand years before present (version 1) - PMIP4 Core experiment design and boundary conditions, Geosci. Model Dev., 9, 2563-2587, https://doi.org/10.5194/gmd-9-2563-2016, 2016.
Jansen, E., Overpeck, J., Briffa, K. R., Duplessy, J. C., Joos, F., Masson-Delmotte, V., Olago, D., Otto-Bliesner, B., Peltier, W. R., Rahmstorf, S., Ramesh, R., Raynaud, D., Rind, D., Solomina, O., Villalba, R., and Zhang, D.: Palaeoclimate, in: Climate Change 2007: The Physical Science Basis. Contribution of Working Group I to the Fourth Assessment Report of the Intergovernmental Panel on Climate Change, edited by: Solomon, S., Qin, D., Manning, M., Chen, Z., Marquis, M., Averyt, K. B., Tignor, M., and Miller, H. L., Cambridge University Press, Cambridge, United Kingdom and New York, NY, USA, 2007.

Jochum, M., Jahn, A., Peacock, S., Bailey, D. A., Fasullo, J. T., Kay, J., Levis, S., and Otto-Bliesner, B.: True to Milankovitch: Glacial Inception in the New Community Climate System Model, J. Climate, 25, 2226-2239, 2012.

Jonkers, L. and Kucera, M.: Global analysis of seasonality in the shell flux of extant planktonic Foraminifera, Biogeosciences, 12, 2207-2226, https://doi.org/10.5194/bg-12-2207-2015, 2015.

Joos, F. and Spahni, R.: Rates of change in natural and anthropogenic radiative forcing over the past 20,000 years, P. Natl. Acad. Sci. USA, 105, 1425-1430, 2008.

Joussaume, S. and Braconnot, P.: Sensitivity of paleoclimate simulation results to season definitions, J. Geophys. Res.-Atmos., 102, 1943-1956, 1997.

Joussaume, S. and Taylor, K. E.: Status of the Paleoclimate Modeling Intercomparison Project, in: Proceedings of the first international AMIP scientific conference, Monterey, USA, 425-430, 1995.

Joussaume, S., Taylor, K. E., Braconnot, P., Mitchell, J. F. B., Kutzbach, J. E., Harrison, S. P., Prentice, I. C., Broccoli, A. J., Abe-Ouchi, A., Bartlein, P. J., Bonfils, C., Dong, B., Guiot, J., Herterich, K., Hewitt, C. D., Jolly, D., Kim, J. W., Kislov, A., Kitoh, A., Loutre, M. F., Masson, V., McAvaney, B., McFarlane, N., de Noblet, N., Peltier, W. R., Peterschmitt, J. Y., Pollard, D., Rind, D., Royer, J. F., Schlesinger, M. E., Syktus, J., Thompson, S., Valdes, P., Vettoretti, G., Webb, R. S., and Wyputta, U.: Monsoon changes for 6000 years ago: Results of 18 simulations from the Paleoclimate Modeling Intercomparison Project (PMIP), Geophys. Res. Lett., 26, 859-862, 1999.

Jouzel, J., Masson-Delmotte, V., Cattani, O., Dreyfus, G., Falourd, S., Hoffmann, G., Minster, B., Nouet, J., Barnola, J.-M., Fisher, H., Gallet, J.-C., Johnsen, S., Leuenberger, M., Loulergue, L., Luethi, D., Oerter, H., Parrenin, F., Raisbeck, G., Raynaud, D., Schilt, A., Schwander, J., Selmo, J., Souchez, R., Spahni, R., Stauffer, B., Steffensen, J. P., Stenni, B., Stocker, T. F., Tison, J.L., Werner, M., and Wolff, E. W.: Orbital and millennial Antarctic climate variability over the past 800,000 years, Science, 317 , 793-796, 2007.

Jungclaus, J. H., Bard, E., Baroni, M., Braconnot, P., Cao, J., Chini, L. P., Egorova, T., Evans, M., González-Rouco, J. F., Goosse, H., Hurtt, G. C., Joos, F., Kaplan, J. O., Khodri, M., Klein Goldewijk, K., Krivova, N., LeGrande, A. N., Lorenz, S. J., Luterbacher, J., Man, W., Maycock, A. C., Meinshausen, M., Moberg, A., Muscheler, R., Nehrbass-Ahles, C., Otto-Bliesner, B. I., Phipps, S. J., Pongratz, J., Rozanov, E., Schmidt, G. A., Schmidt, H., Schmutz, W., Schurer, A., Shapiro, A. I., Sigl, M., Smerdon, J. E., Solanki, S. K., Timmreck, C., Toohey, M., Usoskin, I. G., Wagner, S., Wu, C.-J., Yeo, K. L., Zanchettin, D., Zhang, Q., and Zorita, E.: The PMIP4 contribution to CMIP6 - Part 3: The last millennium, scientific objective, and experimental design for 
the PMIP4 past 1000 simulations, Geosci. Model Dev., 10, 40054033, https://doi.org/10.5194/gmd-10-4005-2017, 2017.

Kageyama, M., Braconnot, P., Harrison, S. P., Haywood, A. M., Jungclaus, J., Otto-Bliesner, B. L., Peterschmitt, J.-Y., AbeOuchi, A., Albani, S., Bartlein, P. J., Brierley, C., Crucifix, M., Dolan, A., Fernandez-Donado, L., Fischer, H., Hopcroft, P. O., Ivanovic, R. F., Lambert, F., Lunt, D. J., Mahowald, N. M., Peltier, W. R., Phipps, S. J., Roche, D. M., Schmidt, G. A., Tarasov, L., Valdes, P. J., Zhang, Q., and Zhou, T.: PMIP4CMIP6: the contribution of the Paleoclimate Modelling Intercomparison Project to CMIP6, Geosci. Model Dev. Discuss., https://doi.org/10.5194/gmd-2016-106, in review, 2016.

Kageyama, M., Albani, S., Braconnot, P., Harrison, S. P., Hopcroft, P. O., Ivanovic, R. F., Lambert, F., Marti, O., Peltier, W. R., Peterschmitt, J.-Y., Roche, D. M., Tarasov, L., Zhang, X., Brady, E. C., Haywood, A. M., LeGrande, A. N., Lunt, D. J., Mahowald, N. M., Mikolajewicz, U., Nisancioglu, K. H., Otto-Bliesner, B. L., Renssen, H., Tomas, R. A., Zhang, Q., Abe-Ouchi, A., Bartlein, P. J., Cao, J., Li, Q., Lohmann, G., Ohgaito, R., Shi, X., Volodin, E., Yoshida, K., Zhang, X., and Zheng, W.: The PMIP4 contribution to CMIP6 - Part 4: Scientific objectives and experimental design of the PMIP4-CMIP6 Last Glacial Maximum experiments and PMIP4 sensitivity experiments, Geosci. Model Dev., 10, 4035-4055, https://doi.org/10.5194/gmd-10-4035-2017, 2017.

Kerwin, M. W.: A regional stratigraphic isochron (ca 8000 C-14 yr BP) from final deglaciation of Hudson Strait, Quat. Res., 46, 89-98, 1996.

Kohfeld, K. and Harrison, S. P.: How well can we simulate past climates? Evaluating the models using global palaeoenvironmental datasets, Quaternary Sci. Rev., 19, 321-346, 2000.

Konare, A., Zakey, A. S., Solmon, F., Giorgi, F., Rauscher, S., Ibrah, S., and $\mathrm{Bi}, \mathrm{X}$. : A regional climate modeling study of the effect of desert dust on the West African monsoon, J. Geophys. Res.Atmos., 113, D12206, https://doi.org/10.1029/2007jd009322, 2008.

Krinner, G., Boucher, O., and Balkanski, Y.: Ice-free glacial northern Asia due to dust deposition on snow, Clim. Dynam., 27, 613625, 2006

Kutzbach, J. E. and Gallimore, R. G.: Sensitivity of a coupled atmosphere mixed layer ocean model to changes in orbital forcing at 9000 years BP, J. Geophys. Res.-Atmos., 93, 803-821, 1988.

Kutzbach, J. E. and Street-Perrott, F. A.: Milankovitch forcing of fluctuations in the level of tropical lakes from 18 to $0 \mathrm{kyr}$ BP, Nature, 317, 130-134, 1985.

Lajeunesse, P. and St-Onge, G.: The subglacial origin of the lake Agassiz-Ojibway final outburst flood, Nat. Geosci., 1, 184-188, 2008.

Larrasoana, J. C., Roberts, A. P., and Rohling, E. J.: Dynamics of Green Sahara periods and their role in Hominin evolution, PLoS ONE, 8, e76514, https://doi.org/10.1371/journal.pone.0076514, 2013.

Larsen, N. K., Kjaer, K. H., Lecavalier, B., Bjork, A. A., Colding, S., Huybrechts, P., Jakobsen, K. E., Kjeldsen, K. K., Knudsen, K. L., Odgaard, B. V., and Olsen, J.: The response of the southern Greenland ice sheet to the Holocene thermal maximum, Geology, 43, 291-294, 2015.

Leduc, G., Schneider, R., Kim, J. H., and Lohmann, G.: Holocene and Eemian sea surface temperature trends as revealed by alkenone and $\mathrm{Mg} / \mathrm{Ca}$ paleothermometry, Quaternary Sci. Rev., 29, 989-1004, 2010.

Lewis, C. F. M., Miller, A. A. L., Levac, E., Piper, D. J. W., and Sonnichsen, G. V.: Lake Agassiz outburst age and routing by Labrador Current and the 8.2 cal ka cold event, Quatern. Int., 260, 83-97, 2012.

Lezine, A. M., Hely, C., Grenier, C., Braconnot, P., and Krinner, G.: Sahara and Sahel vulnerability to climate changes, lessons from Holocene hydrological data, Quaternary Sci. Rev., 30, 30013012, 2011.

Li, G., Harrison, S. P., Prentice, I. C., and Falster, D.: Simulation of tree-ring widths with a model for primary production, carbon allocation, and growth, Biogeosciences, 11, 6711-6724, https://doi.org/10.5194/bg-11-6711-2014, 2014.

Licciardi, J. M., Teller, J. T., and Clark, P. U.: Freshwater Routing by the Laurentide Ice Sheet During the Last Deglaciation, in: Mechanisms of Global Climate Change at Millennial Time Scales, edited by: Clark, P. U., Webb, R. S., and Keigwin, L. D., Geophysical Monograph, 112, 177-201, 1999.

LIGA members: The last interglacial in high latitudes of the Northern Hemisphere: Terrestrial and marine evidence, Quatern. Int., 10-12, 9-28, 1991.

Liu, Z. Y., Zhu, J., Rosenthal, Y., Zhang, X., Otto-Bliesner, B. L., Timmermann, A., Smith, R. S., Lohmann, G., Zheng, W. P., and Timm, O. E.: The Holocene temperature conundrum, P. Natl. Acad. Sci. USA, 111, E3501-E3505, 2014.

Loulergue, L., Schilt, A., Spahni, R., Masson-Delmotte, V., Blunier, T., Lemieux, B., Barnola, J. M., Raynaud, D., Stocker, T. F., and Chappellaz, J.: Orbital and millennial-scale features of atmospheric $\mathrm{CH}_{4}$ over the past 800,000 years, Nature, 453, 383-386, 2008.

Loutre, M. F., Fichefet, T., Goosse, H., Huybrechts, P., Goelzer, H., and Capron, E.: Factors controlling the last interglacial climate as simulated by LOVECLIM1.3, Clim. Past, 10, 1541-1565, https://doi.org/10.5194/cp-10-1541-2014, 2014.

Lozhkin, A. V. and Anderson, P. M.: The last interglaciation in northeast Siberia, Quat. Res., 43, 147-158, 1995.

Luan, Y. H., Braconnot, P., Yu, Y. Q., and Zheng, W. P.: Tropical Pacific mean state and ENSO changes: sensitivity to freshwater flux and remnant ice sheets at $9.5 \mathrm{ka} \mathrm{BP}$, Clim. Dynam., 44, 661678, 2015.

Lunt, D. J., Abe-Ouchi, A., Bakker, P., Berger, A., Braconnot, P., Charbit, S., Fischer, N., Herold, N., Jungclaus, J. H., Khon, V. C., Krebs-Kanzow, U., Langebroek, P. M., Lohmann, G., Nisancioglu, K. H., Otto-Bliesner, B. L., Park, W., Pfeiffer, M., Phipps, S. J., Prange, M., Rachmayani, R., Renssen, H., Rosenbloom, N., Schneider, B., Stone, E. J., Takahashi, K., Wei, W., Yin, Q., and Zhang, Z. S.: A multi-model assessment of last interglacial temperatures, Clim. Past, 9, 699-717, https://doi.org/10.5194/cp-9699-2013, 2013.

Marchant, R., Cleef, A., Harrison, S. P., Hooghiemstra, H., Markgraf, V., van Boxel, J., Ager, T., Almeida, L., Anderson, R., Baied, C., Behling, H., Berrio, J. C., Burbridge, R., Björck, S., Byrne, R., Bush, M., Duivenvoorden, J., Flenley, J., De Oliveira, P., van Geel, B., Graf, K., Gosling, W. D., Harbele, S., van der Hammen, T., Hansen, B., Horn, S., Kuhry, P., Ledru, M.P., Mayle, F., Leyden, B., Lozano-García, S., Melief, A. M., Moreno, P., Moar, N. T., Prieto, A., van Reenen, G., SalgadoLabouriau, M., Schäbitz, F., Schreve-Brinkman, E. J., and Wille, 
M.: Pollen-based biome reconstructions for Latin America at 0, 6000 and 18000 radiocarbon years ago, Clim. Past, 5, 725-767, https://doi.org/10.5194/cp-5-725-2009, 2009.

Marcott, S. A., Shakun, J. D., Clark, P. U., and Mix, A. C.: A Reconstruction of Regional and Global Temperature for the Past 11,300 Years, Science, 339, 1198-1201, 2013.

Marino, G., Rohling, E. J., Rodriguez-Sanz, L., Grant, K. M., Heslop, D., Roberts, A. P., Stanford, J. D., and Yu, J.: Bipolar seesaw control on last interglacial sea level, Nature, 522, 197-201, 2015.

Marlon, J. R., Bartlein, P. J., Daniau, A. L., Harrison, S. P., Maezumi, S. Y., Power, M. J., Tinner, W., and Vanniere, B.: Global biomass burning: a synthesis and review of Holocene paleofire records and their controls, Quaternary Sci. Rev., 65, 5-25, 2013.

Marzeion, B., Jarosch, A. H., and Hofer, M.: Past and future sealevel change from the surface mass balance of glaciers, The Cryosphere, 6, 1295-1322, https://doi.org/10.5194/tc-6-12952012, 2012

Marzin, C., Braconnot, P., and Kageyama, M.: Relative impacts of insolation changes, meltwater fluxes and ice sheets on African and Asian monsoons during the Holocene, Clim. Dynam., 41, 2267-2286, 2013.

Masson-Delmotte, V.. Kageyama, M., Braconnot, P., Charbit, S., Krinner, G., Ritz, C., Guilyardi, E., Jouzel, J., Abe-Ouchi, A., Crucifix, M. Gladstone, R. M., Hewitt, C. D., Kitoh, A., LeGrande, A. N., Marti, O., Merkel, U., Motoi, T., Ohgaito, R., Otto-Bliesner, B., Peltier, W. R., Ross, I., Valdes, P. J., Vettoretti, G., Weber, S. L.,Wolk, F., and Yu, Y.: Past and future polar amplification of climate change: climate model intercomparisons and ice-core constraints, Clim. Dynam., 26, 513-529, 2006.

Masson-Delmotte, V., Stenni, B., Blunier, T., Cattani, O., Chappellaz, J., Cheng, H., Dreyfus, G., Edwards, R. L., Falourd, S., Govin, A., Kawamura, K., Johnsen, S. J., Jouzel, J., Landais, A., Lemieux-Dudon, B., Lourantou, A., Marshall, G., Minster, B., Mudelsee, M., Pol, K., Rothlisberger, R., Selmo, E., and Waelbroeck, C.: Abrupt change of Antarctic moisture origin at the end of Termination II, P. Natl. Acad. Sci. USA, 107, 12091-12094, 2010.

Masson-Delmotte, V., Schulz, M., Abe-Ouchi, A., Beer, J., Ganopolski, A., Gonzalez Rouco, J., Jansen, E., Lambeck, K., Luterbacher, J., Naish, T., Osborn, T., Otto-Bliesner, B., Quinn, T., Ramesh, R., Rojas, M., Shao, X., and Timmermann, A.: Information from paleoclimate archvies, in: The Physical Science Basis. Contribution of Working Group I to the Fifth Assessment Report of the Intergovernmental Panel on Climate Change, edited by: Stocker, T. F., Qin, D., Plattner, G.-K., Tignor, M., Allen, S. K., Boschung, J., Nauels, A., Xia, Y., Bex, V., and Midgley, P. M., Cambridge University Press, Cambridge, United Kingdom and New York, NY, USA, 2013.

Mauri, A., Davis, B. A. S., Collins, P. M., and Kaplan, J. O.: The influence of atmospheric circulation on the mid-Holocene climate of Europe: a data-model comparison, Clim. Past, 10, 1925-1938, https://doi.org/10.5194/cp-10-1925-2014, 2014.

McGee, D., deMenocal, P. B., Winckler, G., Stuut, J. B. W., and Bradtmiller, L. I.: The magnitude, timing and abruptness of changes in North African dust deposition over the last 20,000 yr, Earth Planet. Sc. Lett., 371-372, 163-176, 2013.

McKay, N. P., Overpeck, J. T., and Otto-Bliesner, B. L.: The role of ocean thermal expansion in Last Inter- glacial sea level rise, Geophys. Res. Lett., 38, L14605, https://doi.org/10.1029/2011GL048280, 2011.

McKay, R., Naish, T., Powell, R., Barrett, P., Scherer, R., Talarico, F., Kyle, P., Monien, D., Kuhn, G., Jackolski, C., and Williams, T.: Pleistocene variability of Antarctic Ice Sheet extent in the Ross Embayment, Quaternary Sci. Rev., 34, 93-112, 2012.

McManus, J. F., Oppo, D. W., and Cullen, J. L.: A 0.5-millionyear record of millennial-scale climate variability in the North Atlantic, Science, 283, 971-975, 1999.

Mercer, J. H.: West Antarctic Ice Sheet And $\mathrm{CO}_{2}$ greenhouse effect - threat of disaster, Nature, 271, 321-325, 1978.

Miller, R. L., Perlwitz, J., and Tegen, I.: Feedback upon dust emission by dust radiative forcing through the planetary boundary layer, J. Geophys. Res.-Atmos., 109, D24209, https://doi.org/10.1029/2004JD004912, 2004.

Mitchell, L., Brook, E., Lee, J. E., Buizert, C., and Sowers, T.: Constraints on the Late Holocene Anthropogenic Contribution to the Atmospheric Methane Budget, Science, 342, 964-966, 2013.

Moberg, A.: Comparisons of simulated and observed Northern Hemisphere temperature variations during the past millennium - selected lessons learned and problems encountered, Tellus B, 65, https://doi.org/10.3402/tellusb.v65i0.19921, 2013.

Monnin, E., Indermuhle, A., Dallenbach, A., Fluckiger, J., Stauffer, B., Stocker, T. F., Raynaud, D., and Barnola, J. M.: Atmospheric $\mathrm{CO}_{2}$ concentrations over the last glacial termination, Science, 291, 112-114, 2001.

Monnin, E., Steig, E. J., Siegenthaler, U., Kawamura, K., Schwander, J., Stauffer, B., Stocker, T. F., Morse, D. L., Barnola, J. M., Bellier, B., Raynaud, D., and Fischer, H.: Evidence for substantial accumulation rate variability in Antarctica during the Holocene, through synchronization of $\mathrm{CO}_{2}$ in the Taylor Dome, Dome C and DML ice cores, Earth Planet. Sc. Lett., 224, 45-54, 2004.

Mor, A. S., Yam, R., Bianchi, C., Kunz-Pirrung, M., Gersonde, R., and Shemesh, A.: Variable sequence of events during the past seven terminations in two deep-sea cores from the Southern Ocean, Quaternary Res., 77, 317-325, 2012.

Morrill, C., LeGrande, A. N., Renssen, H., Bakker, P., and Otto-Bliesner, B. L.: Model sensitivity to North Atlantic freshwater forcing at $8.2 \mathrm{ka}$, Clim. Past, 9, 955-968, https://doi.org/10.5194/cp-9-955-2013, 2013.

Muschitiello, F., Zhang, Q., Sundqvist, H. S., Davies, F. J., and Renssen, H.: Arctic climate response to the termination of the African Humid Period, Quaternary Sci. Rev., 125, 91-97, 2015.

Myhre, G., Highwood, E. J., Shine, K. P., and Stordal, F.: New estimates of radiative forcing due to well mixed greenhouse gases, Geophys. Res. Lett., 25, 2715-2718, 1998.

NEEM Community Members: Eemian interglacial reconstructed from a Greenland folded ice core, Nature, 493, 489-494, 2013.

NGRIP Project Members: High-resolution record of Northern Hemisphere climate extending into the last interglacial period, Nature, 431, 147-151, 2004

Nicholl, J. A. L., Hodell, D. A., Naafs, B. D. A., Hillaire-Marcel, C., Channell, J. E. T., and Romero, O. E.: A Laurentide outburst flooding event during the last interglacial period, Nat. Geosci., 5 , 901-904, 2012.

Notz, D., Jahn, A., Holland, M., Hunke, E., Massonnet, F., Stroeve, J., Tremblay, B., and Vancoppenolle, M.: The CMIP6 SeaIce Model Intercomparison Project (SIMIP): understanding sea 
ice through climate-model simulations, Geosci. Model Dev., 9, 3427-3446, https://doi.org/10.5194/gmd-9-3427-2016, 2016.

Nowicki, S. M. J., Payne, A., Larour, E., Seroussi, H., Goelzer, H., Lipscomb, W., Gregory, J., Abe-Ouchi, A., and Shepherd, A.: Ice Sheet Model Intercomparison Project (ISMIP6) contribution to CMIP6, Geosci. Model Dev., 9, 4521-4545, https://doi.org/10.5194/gmd-9-4521-2016, 2016.

Oliver, K. I. C., Hoogakker, B. A. A., Crowhurst, S., Henderson, G. M., Rickaby, R. E. M., Edwards, N. R., and Elderfield, H.: A synthesis of marine sediment core $\delta^{13} \mathrm{C}$ data over the last 150000 years, Clim. Past, 6, 645-673, https://doi.org/10.5194/cp-6-6452010, 2010.

Otto, J., Raddatz, T., Claussen, M., Brovkin, V., and Gayler, V.: Separation of atmosphere-ocean-vegetation feedbacks and synergies for mid-Holocene climate, Geophys. Res. Lett., 36, L09701, https://doi.org/10.1029/2009g1037482, 2009.

Otto-Bliesner, B. L., Rosenbloom, N., Stone, E. J., McKay, N. P., Lunt, D. J., Brady, E. C., and Overpeck, J. T.: How warm was the last interglacial? New model-data comparisons, Philos. T. R. Soc. A, 371, 2001, https://doi.org/10.1098/rsta.2013.0097, 2013.

Pausata, F. S. R., Messori, G., and Zhang, Q.: Impacts of dust reduction on the northward expansion of the African monsoon during the Green Sahara period, Earth Planet. Sc. Lett., 434, 298-307, 2016.

Perez-Sanz, A., Li, G., González-Sampériz, P., and Harrison, S. P.: Evaluation of modern and mid-Holocene seasonal precipitation of the Mediterranean and northern Africa in the CMIP5 simulations, Clim. Past, 10, 551-568, https://doi.org/10.5194/cp-10551-2014, 2014.

Perlwitz, J., Tegen, I., and Miller, R. L.: Interactive soil dust aerosol model in the GISS GCM 1. Sensitivity of the soil dust cycle to radiative properties of soil dust aerosols, J. Geophys. Res.-Atmos., 106, 18167-18192, 2001.

Petit-Maire, N.: Natural variability of the Earth's environments: the last two climatic extremes $(18000 \pm 2000$ and $8000 \pm 1000 \mathrm{yrs}$ BP), Comptes Rendus De L Academie Des Sciences Serie Ii Fascicule a-Sciences De La Terre Et Des Planetes, 328, 273-279, https://doi.org/10.1016/S1251-8050(99)80307-3, 1999.

Pickett, E. J., Harrison, S. P., Hope, G., Harle, K., Dodson, J. R., Kershaw, A. P., Prentice, I. C., Backhouse, J., Colhoun, E. A., D’Costa, D., Flenley, J., Grindrod, J., Haberle, S., Hassell, C., Kenyon, C., Macphail, M., Martin, H., Martin, A. H., McKenzie, M., Newsome, J. C., Penny, D., Powell, J., Raine, J. I., Southern, W., Stevenson, J., Sutra, J. P., Thomas, I., van der Kaars, S., and Ward, J.: Pollen-based reconstructions of biome distributions for Australia, Southeast Asia and the Pacific (SEAPAC region) at 0, 6000 and 18000 (14)C yr BP, J. Biogeogr., 31, 1381-1444, 2004.

PMIP4 repository: Forcing and boundary condition data sets, available at: https://pmip4.lsce.ipsl.fr/doku.php/exp_design:index, 2017.

Potenza, M. A. C., Albani, S., Delmonte, B., Villa, S., Sanvito, T., Paroli, B., Pullia, A., Baccolo, G., Mahowald, N., and Maggi, V.: Shape and size constraints on dust optical properties from the Dome C ice core, Antarctica, Sci. Rep., 6, https://doi.org/10.1038/srep28162, 2016.

Prentice, I. C., Jolly, D., and BIOME 6000 participants: MidHolocene and glacial-maximum vegetation geography of the northern continents and Africa, J. Biogeogr., 27, 507-519, 2000.
Renssen, H., Seppa, H., Heiri, O., Roche, D. M., Goosse, H., and Fichefet, T.: The spatial and temporal complexity of the Holocene thermal maximum, Nat. Geosci., 2, 410-413, 2009.

Renssen, H., Seppa, H., Crosta, X., Goosse, H., and Roche, D. M.: Global characterization of the Holocene Thermal Maximum, Quaternary Sci. Rev., 48, 7-19, 2012.

Risebrobakken, B., Balbon, E., Dokken, T., Jansen, E., Kissel, C., Labeyrie, L., Richter, T., and Senneset, L.: The penultimate deglaciation: High-resolution paleoceanographic evidence from a north-south transect along the eastern Nordic Seas, Earth Planet. Sc. Lett., 241, 505-516, 2006.

Rosell-Mele, A. and Prahl, F. G.: Seasonality of U-37(K)' temperature estimates as inferred from sediment trap data, Quaternary Sci. Rev., 72, 128-136, 2013.

Roy, M., Dell'Oste, F., Veillette, J. J., de Vernal, A., Helie, J. F., and Parent, M.: Insights on the events surrounding the final drainage of Lake Ojibway based on James Bay stratigraphic sequences, Quaternary Sci. Rev., 30, 682-692, 2011.

Royer, A., Deangelis, M., and Petit, J. R.: A 30000 year record of physical and optical-properties of microparticles from an East Antarctic ice core and implications for paleoclimate reconstruction models, Climatic Change, 5, 381-412, 1983.

Saraswat, R., Lea, D. W., Nigam, R., Mackensen, A., and Naik, D. K.: Deglaciation in the tropical Indian Ocean driven by interplay beween the regional monsoon and global teleconnections, Earth Planet. Sc. Lett., 375, 166-175, 2013.

Schilt, A., Baumgartner, M., Schwander, J., Buiron, D., Capron, E., Chappellaz, J., Loulergue, L., Schüpbach, S., Spahni, R., Fischer, H., and Stocker, T. F.: Atmospheric nitrous oxide during the last 140000 years, Earth Planet. Sc. Lett., 300, 33-43, 2010a.

Schilt, A., Baumgartner, M., Blunier, T., Schwander, J., Spahni, R., Fischer, H., and Stocker, T. F.: Glacial-interglacial and millennial-scale variations in the atmospheric nitrous oxide concentration during the last 800000 years, Quaternary Sci. Rev., 29, 182-192, 2010b.

Schmidt, G. A., Annan, J. D., Bartlein, P. J., Cook, B. I., Guilyardi, E., Hargreaves, J. C., Harrison, S. P., Kageyama, M., LeGrande, A. N., Konecky, B., Lovejoy, S., Mann, M. E., Masson-Delmotte, V., Risi, C., Thompson, D., Timmermann, A., Tremblay, L.B., and Yiou, P.: Using palaeo-climate comparisons to constrain future projections in CMIP5, Clim. Past, 10, 221-250, https://doi.org/10.5194/cp-10-221-2014, 2014.

Schneider, R., Schmitt, J., Köhler, P., Joos, F., and Fischer, H.: A reconstruction of atmospheric carbon dioxide and its stable carbon isotopic composition from the penultimate glacial maximum to the last glacial inception, Clim. Past, 9, 2507-2523, https://doi.org/10.5194/cp-9-2507-2013, 2013.

Shakun, J. D., Clark, P. U., He, F., Marcott, S. A., Mix, A. C., Liu, Z. Y., Otto-Bliesner, B., Schmittner, A., and Bard, E.: Global warming preceded by increasing carbon dioxide concentrations during the last deglaciation, Nature, 484, 49-54, 2012.

Siegenthaler, U., Stocker, T. F., Monnin, E., Lüthi, D., Schwander, J., Stauffer, B., Raynaud, D., Barnola, J.-M., Fischer, H., Masson-Delmotte, V., and Jouzel, J.: Stable Carbon Cycle: Climate Relationship During the Late Pleistocene, Science, 310, 1313-1317, https://doi.org/10.1126/science.1120130, 2005.

Sime, L. C., Risi, C., Tindall, J. C., Sjolte, J., Wolff, E. W., MassonDelmotte, V., and Capron, E.: Warm climate isotopic simula- 
tions: what do we learn about interglacial signals in Greenland ice cores?, Quaternary Sci. Rev., 67, 59-80, 2013.

Sinclair, G., Carlson, A. E., Mix, A. C., Lecavalier, B. S., Milne, G., Mathias, A., Buizert, C., and DeConto, R.: Diachronous retreat of the Greenland ice sheet during the last deglaciation, Quaternary Sci. Rev., 145, 243-258, 2016.

Spahni, R., Schwander, J., Fluckiger, J., Stauffer, B., Chappellaz, J., and Raynaud, D.: The attenuation of fast atmospheric $\mathrm{CH}_{4}$ variations recorded in polar ice cores, Geophys. Res. Lett., 30, 1571, https://doi.org/10.1029/2003gl017093, 2003.

Spahni, R., Chappellaz, J., Stocker, T. F., Loulergue, L., Hausammann, G., Kawamura, K., Fluckiger, J., Schwander, J., Raynaud, D., Masson-Delmotte, V., and Jouzel, J.: Atmospheric methane and nitrous oxide of the late Pleistocene from Antarctic ice cores, Science, 310, 1317-1321, 2005.

Steig, E. J., Huybers, K., Singh, H. A., Steiger, N. J., Ding, Q. H., Frierson, D. M. W., Popp, T., and White, J. W. C.: Influence of West Antarctic Ice Sheet collapse on Antarctic surface climate, Geophys. Res. Lett., 42, 4862-4868, 2015.

Stirling, C. H., Esat, T. M. Lambeck, K., and McCulloch, M. T.: Timing and duration of the Last Interglacial: evidence for a resticted interval of widespread coral reef growth, Earth Planet. Sc. Lett., 160, 745-762, 1998.

Stone, E. J., Capron, E., Lunt, D. J., Payne, A. J., Singarayer, J. S., Valdes, P. J., and Wolff, E. W.: Impact of meltwater on highlatitude early Last Interglacial climate, Clim. Past, 12, 19191932, https://doi.org/10.5194/cp-12-1919-2016, 2016.

Stoner, J. S., Channell, J. E. T., and Hillairemarcel, C.: Magneticproperties of deep-sea sediments off southwest greenland - evidence for major differences between the last 2 deglaciations, Geology, 23, 241-244, 1995.

Sutter, J., Gierz, P., Grosfeld, K., Thoma, M., and Lohmann, G.: Ocean temperature thresholds for Last Interglacial West Antarctic Ice Sheet collapse, Geophys. Res. Lett., 43, 2675-2682, 2016.

Svensson, A., Andersen, K. K., Bigler, M., Clausen, H. B., DahlJensen, D., Davies, S. M., Johnsen, S. J., Muscheler, R., Parrenin, F., Rasmussen, S. O., Röthlisberger, R., Seierstad, I., Steffensen, J. P., and Vinther, B. M.: A 60000 year Greenland stratigraphic ice core chronology, Clim. Past, 4, 47-57, https://doi.org/10.5194/cp-4-47-2008, 2008.

Tegen, I., Harrison, S. P., Kohfeld, K., Prentice, I. C., Coe, M., and Heimann, M.: Impact of vegetation and preferential source areas on global dust aerosol: Results from a model study, J. Geophys. Res.-Atmos., 107, 4576, https://doi.org/10.1029/2001JD000963, 2002.

Teller, J. T., Leverington, D. W., and Mann, J. D.: Freshwater outbursts to the oceans from glacial Lake Agassiz and their role in climate change during the last deglaciation, Quaternary Sci. Rev., 21, 879-887, 2002.

Thompson, D. M., Ault, T. R., Evans, M. N., Cole, J. E., and EmileGeay, J.: Comparison of observed and simulated tropical climate trends using a forward model of coral $\delta^{18} \mathrm{O}$, Geophys. Res. Lett., 38, L14706, https://doi.org/10.1029/2011g1048224, 2011.

Tierney, J. E., Pausata, F. S. R., and deMenocal, P. B.: Rainfall regimes of the Green Sahara, Science Advances, 3, e1601503, 2017.
Tschumi, J. and Stauffer, B.: Reconstructing past atmospheric $\mathrm{CO}_{2}$ concentration based on ice-core analyses: open questions due to in situ production of $\mathrm{CO}_{2}$ in the ice J. Glaciol., 46, 45-53, 2000.

Turney, C. S. M. and Jones, R. T.: Does the Agulhas Current amplify global temperatures during super-interglacials?, J. Quaternary Sci., 25, 839-843, 2010.

Veres, D., Bazin, L., Landais, A., Toyé Mahamadou Kele, H., Lemieux-Dudon, B., Parrenin, F., Martinerie, P., Blayo, E., Blunier, T., Capron, E., Chappellaz, J., Rasmussen, S. O., Severi, M., Svensson, A., Vinther, B., and Wolff, E. W.: The Antarctic ice core chronology (AICC2012): an optimized multi-parameter and multi-site dating approach for the last 120 thousand years, Clim. Past, 9, 1733-1748, https://doi.org/10.5194/cp-9-17332013, 2013.

Viau, A. E. and Gajewski, K.: Reconstructing Millennial-Scale, Regional Paleoclimates of Boreal Canada during the Holocene, J. Climate, 22, 316-330, 2009.

Viau, A. E., Gajewski, K., Sawada, M. C., and Fines, P.: Millennialscale temperature variations in North America during the Holocene, J. Geophys. Res.-Atmos., 111, 31703-31716, 2006.

Vinoj, V., Rasch, P. J., Wang, H. L., Yoon, J. H., Ma, P. L., Landu, K., and Singh, B.: Short-term modulation of Indian summer monsoon rainfall by West Asian dust, Nat. Geosci., 7, 308-313, 2014.

Wagner, A. J., Morrill, C., Otto-Bliesner, B. L., Rosenbloom, N., and Watkins, K. R.: Model support for forcing of the $8.2 \mathrm{ka}$ event by meltwater from the Hudson Bay ice dome, Clim. Dynam., 41, 2855-2873, 2013.

Wanner, H., Beer, J., Butikofer, J., Crowley, T. J., Cubasch, U., Fluckiger, J., Goosse, H., Grosjean, M., Joos, F., Kaplan, J. O., Kuttel, M., Muller, S. A., Prentice, I. C., Solomina, O., Stocker, T. F., Tarasov, P., Wagner, M., and Widmann, M.: Mid- to Late Holocene climate change: an overview, Quaternary Sci. Rev., 27, 1791-1828, 2008.

Winsor, K., Carlson, A. E., Klinkhammer, G. P., Stoner, J. S., and Hatfield, R. G.: Evolution of the northeast Labrador Sea during the last interglaciation, Geochem. Geophy. Geosy., 13, https://doi.org/10.1029/2012GC004263, 2012.

Wittenberg, A. T.: Are historical records sufficient to constrain ENSO simulations?, Geophys. Res. Lett., 36, L12702, https://doi.org/10.1029/2009GL038710, 2009.

Wohlfahrt, J., Harrison, S. P., and Braconnot, P.: Synergistic feedbacks between ocean and vegetation on mid- and high-latitude climates during the mid-Holocene, Clim. Dynam., 22, 223-238, 2004.

Yin, Q. Z. and Berger, A.: Individual contribution of insolation and $\mathrm{CO}_{2}$ to the interglacial climates of the past 800000 years, Clim. Dynam., 38, 709-724, https://doi.org/10.1007/s00382011-1013-5, 2012.

Yoshioka, M., Mahowald, N. M., Conley, A. J., Collins, W. D., Fillmore, D. W., Zender, C. S., and Coleman, D. B.: Impact of desert dust radiative forcing on Sahel precipitation: Relative importance of dust compared to sea surface temperature variations, vegetation changes, and greenhouse gas warming, J. Climate, 20, 14451467, 2007. 